UNIVERSIDADE DE BRASÍLIA - UnB

Centro de Excelência Em Turismo - CET

Pós-Graduação em Gestão e Marketing do Turismo

\title{
BRASÍLIA, A TERRA PROMETIDA TURISMO MÍSTICO E RELIGIOSO NA CAPITAL DO PAÍS
}

Autor: James Gama

Brasília, março de 2004 
Universidade de Brasília - UnB

Centro de Excelência Em Turismo - CET

\title{
BRASÍLIA, A TERRA PROMETIDA \\ Turismo Místico e Religioso na capital do país
}

\author{
Autor: James Borralho Gama \\ Orientador: Eraldo Alves da Cruz
}

Monografia apresentada ao Centro de Excelência em Turismo da Universidade de Brasília como requisito para a obtenção do certificado de PósGraduação em Gestão e Marketing do Turismo.

Brasília, 22 de março de 2004 
UNIVERSIDADE DE BRASÍLIA

Centro de Excelência Em Turismo

Pós-Graduação em Gestão e Marketing do Turismo

\section{BRASÍLIA, A TERRA PROMETIDA}

TURISMO MÍSTICO E RELIGIOSO NA CAPITAL DO PAÍS

Autor: James Borralho Gama

Banca Examinadora

Membro da Banca

Brasília, 22 de março de 2004 
Dedico esta monografia ao Santo que inspirou este trabalho,

Dom Bosco, cuja ligação remonta ao Colégio onde estudei na infância, em São Luís do Maranhão. Dedico também a Brasília, cidade que me acolheu e que aprendi a amar.

E ao meu pai, Orlando Gama, um apaixonado pela capital, que me propiciou a oportunidade de estar aqui e viver este momento. 
Agradeço a Deus pelo aprendizado nesta vida. À minha mulher, Bruna Teresa, por quem me deixei arrebatar. Aos meus filhos queridos, Luana, Lucas e Laura, pelo amor e compreensão. À minha mãe, Celeste, pelo apoio sempre presente. Aos irmãos, Jones e Jane, pelo carinho incondicional. Ao Mariano, amigo cuja fé motivou este trabalho. Aos colegas pelos bons tempos de convivência. E a todos os amigos que colaboraram para este trabalho. 


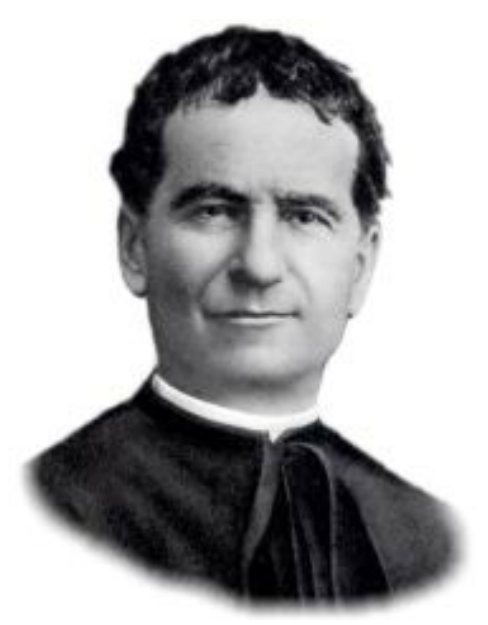

"Mas não era tudo.

Entre o grau 15 e o 20, havia uma enseada bastante extensa, que partia do ponto onde se formava um lago.

Disse então uma voz repetidamente:

- Quando se vierem cavar as minas escondidas em meio a estes montes, aparecerá aqui a Terra Prometida, que jorrará leite e mel.

Será uma riqueza inconcebível".

Dom Bosco, 1883. 


\section{SUMÁRIO}

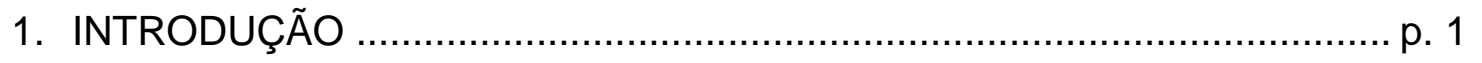

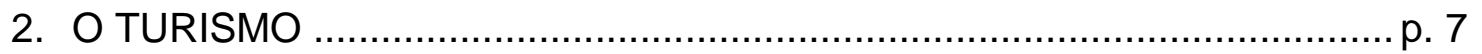

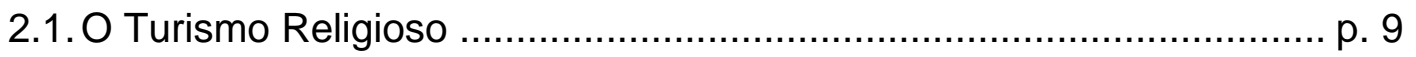

2.2. O Turismo Místico e Esotérico ........................................................p. 13

2.3. O Turismo Espiritual ................................................................... p. 18

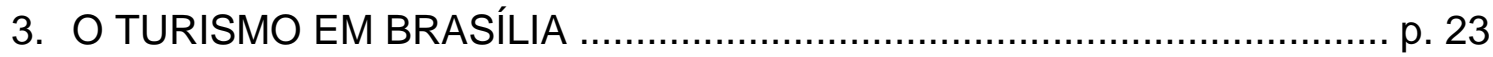

3.1. O Turismo Religioso, Místico e Espiritual na Capital Federal ..............p. 25

3.2. Brasília Mística .....................................................................p. 27

3.3. Brasília Religiosa ................................................................. p. 30

3.3.1. Eventos religiosos na capital do país ...................................p. 31

3.3.2. Igrejas, templos e comunidades religiosas .......................... p. 34

3.3.3. Esculturas, marcos e monumentos religiosos ...........................p. 35

3.3.4. Templos e monumentos em homenagem a Dom Bosco ........... p. 36

4. BRASÍLIA, A TERRA PROMETIDA …............................................... p. 38

5. A NOVA CAPITAL - A CONSTRUÇÃO DA PROFECIA …..................... p. 42

6. MONTEIRO LOBATO, O ARAUTO DA PROFECIA ............................... p. 47

7. O MÍSTICO JK. ...E CUMPRE-SE A PROFECIA ...................................p. 50

8. ISRAEL PINHEIRO, O DEVOTO HOMENAGEIA O SANTO .....................p. 54

9. DOM BOSCO, PADROEIRO - A CIDADE SE CURVA AO PROFETA ......p. 56

10. JOÃO BOSCO - PERFIL DO PROFETA ….................................. p. 58

11. O SONHO PROFÉTICO ............................................................. p. 60

12. DECIFRANDO A PROFECIA ...................................................... 62

13. SALESIANOS NO BRASIL - A FORÇA DA CONGREGAÇÃO .................p. 69

14. PROCISSÃO, ROCK E ORAÇÕES - A FESTA DO PADROEIRO ........... p. 71

15. CONCLUSÃO .............................................................................. 73

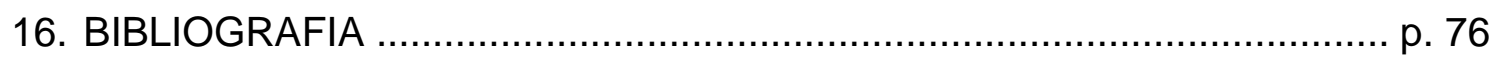

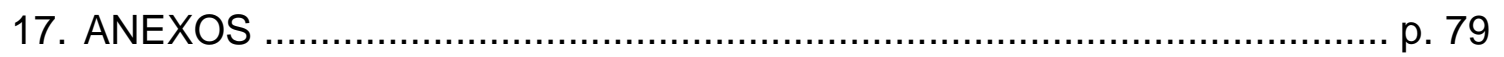




\section{INTRODUÇÃO}

Construída em pleno cerrado, no planalto central, para ser a sede do governo e integrar os brasileiros de todo o país, a Brasília, fundada pelo visionário Presidente Juscelino Kubitschek, antes mesmo de ser inaugurada, já atraía religiosos, espiritualistas e místicos de todo o Brasil e visitantes do exterior que acreditavam ser a cidade o berço de uma nova civilização, de onde surgiria uma nova era de prosperidade espiritual.

Considerada por muitos, capital ecumênica, por reunir todas as religiões, seitas e crenças, que aqui convivem pacificamente nos templos espalhados pela cidade, Brasília tornou-se um centro de referência da fé. Estima-se que existam mais de 2.600 templos de diversas seitas e religiões no Distrito Federal, desde católicos e protestantes a seitas orientais, passando por cultos africanos e indígenas.

São 18 os principais templos da cidade, incluindo a Catedral Metropolitana, concebida pelo arquiteto Oscar Niemeyer, igrejas evangélicas, templos da ortodoxia e templos budistas como o da Terra Pura, o templo dos Seicho-no-iê, e ainda o templo da Legião da Boa Vontade, de tendência ecumênica e um dos pontos mais visitados pelos turistas que chegam à capital do país.

Além da pluralidade religiosa Brasília possui uma característica mística muito grande. O misticismo está espalhado por toda a cidade. No desenho urbano, na arquitetura. São quase mil organizações esotéricas, religiosas e filosóficas que cada vez mais chamam a atenção dos turistas e dos que buscam o autoconhecimento e o desenvolvimento da espiritualidade interior.

As raízes do misticismo da cidade remetem à profecia de Dom Bosco, um padre italiano, que profetizou, em 1883, o surgimento de uma nova cidade, exatamente onde se construiu Brasília - "Entre os paralelos $15^{\circ}$ e $20^{\circ}$, surgirá uma cidade que manará leite e mel para toda a Terra". Situada nas proximidades 
do paralelo de $15^{\circ}$, Brasília é tida pelos místicos como a "Terra Prometida", vislumbrada por Dom Bosco.

Há, ainda, os que encontram semelhanças entre Brasília e o místico Egito Antigo. Para eles, a cidade construída por JK seria na verdade a materialização da antiga cidade egípcia de Aton e o próprio JK a reencarnação do faraó egípcio Akhenaton. Entre as características apontadas estão: o traçado de Brasília em forma do pássaro egípcio íbis, e os muitos prédios em formas de pirâmide 1 .

Além da mística em torno de sua criação, Brasília também é o centro de uma região ecumênica. No entorno da capital, há pelo menos duas grandes comunidades de sincretismo religioso: a Cidade Eclética, em Santo Antônio do Descoberto, onde vivem 1.500 pessoas, e o Vale do Amanhecer, perto de Planaltina, que existe há mais de 30 anos. Na saída para a BR-040, existe também a Cidade da Paz, que abriga a Universidade Holística Internacional de Brasília.

As coincidências cabalísticas, estruturais e históricas com outras civilizações, levaram os teóricos esotéricos a atribuir a Brasília o título de capital da civilização do terceiro milênio, ou capital da civilização aquariana.

De acordo com videntes, Brasília está exposta a fortes energias cósmicas. As chapadas que a rodeiam são um perfeito campo de pouso para visitantes extraterrestres, segundo os ufólogos, que organizam vigílias noturnas periódicas para contatos de qualquer grau com outras formas de vida do Cosmo.

Brasília é a porta de entrada para a cidade de Alto Paraíso, localizada na entrada da Chapada dos Veadeiros, a pouco mais de $200 \mathrm{~km}$ da capital, considerada a mais mística do país, reunindo, entre seus 8.000 habitantes, representantes de cerca de 40 religiões e seitas e sete grandes templos.

\footnotetext{
${ }^{1}$ Iara Kern, De Aknaton a JK - das Pirâmides a Brasília, pág. 38.
} 
Situada a 1.300 metros de altitude, Alto Paraíso fica localizada no paralelo $14^{\circ}$, o mesmo que corta a mítica Machu Pichu. A cidade, que desde 1970, vem recebendo pessoas de diversos lugares do mundo interessadas em formar as bases de uma sociedade mais voltada para a espiritualidade, é considerada pela comunidade esotérica mundial, par a par com Brasília, como um dos berços da civilização do Terceiro Milênio.

Acredita-se que todas essas características expostas acima fazem de Brasília uma cidade com potencial para o desenvolvimento do turístico religioso, místico e espiritual.

A proposta desse trabalho é reunir dados e informações que confirmem a vocação da cidade como centro de referência da fé, sem o questionamento das doutrinas e dogmas que caracterizam cada uma dessas crenças, apenas constatando a sua existência, estrutura disponível, bem como os "serviços" oferecidos aos seus "usuários".

A partir da organização das informações, trata-se de estabelecer a possibilidade de fortalecimento dessa vocação, tendo como fator de atração turística para Brasília o evento em que se comemora o Aniversário do SonhoVisão de Dom Bosco, realizado todos os anos no último domingo de agosto.

Embora, a padroeira oficial de Brasília seja Nossa Senhora Aparecida, o Santo italiano São João Bosco ganhou depois a condição de segundo Patrono de Brasília ou, precisamente, aequis principalis "igualmente principal”, por ter previsto em sonho o surgimento da Terra Prometida, entre os paralelos $15^{\circ}$ e $20^{\circ}$, a mesma localização onde 77 anos depois seria construída a capital do país.

Com base nas crenças místicas, religiosas e espirituais presentes em Brasília, evidenciadas neste trabalho, e da constatação de que a profecia da Terra Prometida está definitivamente ligada à capital do país, pretende-se apresentar a Festa de Dom Bosco como uma grande opção de evento turístico místico, religioso e espiritual, com potencial para atrair milhares de fiéis e peregrinos a Brasília. 
Para a melhor compreensão deste trabalho, trata-se, inicialmente, de apresentar os conceitos de turismo, bem como as definições para os vários segmentos que hoje compõem as demandas turísticas, especialmente as derivações do turismo religioso, estabelecendo e justificando as diferenças entre turismo religioso, turismo místico e turismo espiritual.

Em seguida, apresenta-se um panorama do setor turismo em Brasília, seus produtos e vocações. Destaca-se o potencial da cidade para desenvolver o turismo religioso, místico e espiritual, expondo-se os elementos que compõem as Brasílias mística e religiosa, incluindo seus equipamentos turísticos, como igrejas, templos, marcos e monumentos, especialmente, os que homenageiam Dom Bosco.

Adiante, coloca-se a capital do país frente à profecia de Dom Bosco, analisando-se os aspectos místicos, crenças, mitos e coincidências incríveis que convergem para a afirmação de que a cidade fundada por Juscelino Kubitschek é a Terra Prometida sonhada pelo Santo italiano. Aceite-se ou não, o mito virou realidade.

No capítulo seguinte, busca-se resgatar a história da construção de Brasília, desde as primeiras idéias mudancistas da capital para o interior do país, as Missões de exploração no Planalto goiano, até a fundação da cidade por JK. Destacando-se alguns personagens importantes nesse processo, que contribuíram para construir a Brasília mitológica da Terra Prometida.

A seguir, resgata-se a história da descoberta do sonho de Dom Bosco no país, suas primeiras interpretações e o relevante papel do escritor Monteiro Lobato nesse contexto.

O perfil místico do construtor de Brasília, o ex-presidente Juscelino, é curiosamente revelado como mais um elemento a compor a crença na profecia de Dom Bosco e dele próprio, JK, de que a cidade será a Capital do Terceiro Milênio. 
Recupera-se, ainda, a história de outro personagem importante na história da construção de Brasília e fundamental para a vinculação da cidade com o seu profeta, Dom Bosco. Trata-se do engenheiro Israel Pinheiro, fiel devoto do Santo João Bosco, a quem homenageou com a construção da Ermida Dom Bosco, a primeira obra de alvenaria na nova capital.

Aborda-se a escolha do padroeiro da nova capital, um processo que culminou com a indicação de Nossa Senhora Aparecida, padroeira do Brasil, sugestão acolhida por JK. Pouco tempo depois, porém, prevaleceu a forte ligação da cidade com Dom Bosco e Brasília ganhou o seu segundo padroeiro, igualmente principal.

É importante entender quem foi Dom Bosco, o Santo italiano que sonhava com o Brasil. Um pequeno relato sobre a vida de São João Bosco, que dedicou sua vida à educação dos jovens e decidia praticamente tudo após sonhos premonitórios, ajudam a situar o contexto em que teve a visão da Terra Prometida.

O famoso sonho-visão, o "fato maravilhoso" que anuncia a Terra de uma riqueza inconcebível, entre os paralelos 15 e 20, onde jorrará leite e mel, é descrito conforme o próprio Dom Bosco relatou aos membros da Congregação Salesiana, após uma noite inteira de "viagem" pela América do Sul.

A seguir, trata-se de analisar a profecia de Dom Bosco, a partir de interpretações, inclusive de Salesianos e do próprio Papa João Paulo II, que corroboram a afirmativa de que Dom Bosco sonhou mesmo com Brasília e esta seria a Terra Prometida que ele vislumbrara.

A presença dos Salesianos no Brasil e a força da Congregação que representam em todo o mundo são fundamentais para determinar a importante participação dos devotos de Dom Bosco no evento que comemora o aniversário do sonho-visão de Dom Bosco. 
Finalmente, trata-se de discorrer sobre o evento em si, a sua tradição, a participação dos fiéis, autoridades e da população de Brasília em geral, na grande festa do padroeiro da cidade. E, da oportunidade que se apresenta de se investir no seu incremento como fator de atração turística para Brasília. Um evento único no país, que soma a força mística da cidade à profecia da Terra Prometida e à devoção de milhares de fiéis salesianos no Brasil e no mundo ao seu profeta. 


\section{O TURISMO}

O conceito de turismo vem mudando ao longo da história. À dinâmica dos processos de deslocamentos entre um destino e outro foram incorporadas as diversas motivações que levam as pessoas a viajar, mesmo não sendo o lazer a principal delas. Dessa forma, ganharam status de "turísticos" os deslocamentos com os mais variados objetivos, como negócios, congressos, saúde, dentre outros considerados nas estatísticas oficiais.

De acordo com Mário Beni, ${ }^{2}$ a conceituação do turismo não pode ficar limitada a uma simples definição, já que é um fenômeno que ocorre em vários contextos da realidade social e em distintos campos de estudo, onde é explicado conforme as diferentes correntes de pensamento.

Entre as várias definições destaca-se o conceito da Organização Mundial do Turismo (OMT), que considera o turismo uma modalidade de deslocamento espacial, que envolve a utilização de algum meio de transporte e ao menos um pernoite no destino. Este conceito motivou, segundo Cruz, ${ }^{3}$ a chamada segmentação do turismo, que passou a ser classificado de acordo com a motivação - turismo de negócios, turismo de eventos, turismo de saúde, turismo religioso etc.

Embora não haja uma unanimidade conceitual, o turismo conquistou na prática a condição de uma das principais atividades da economia mundial. São 52 segmentos da economia envolvidos direta e indiretamente com a atividade turística, movimentando U\$3,4 trilhões ao ano, responsáveis pela ocupação de 260 milhões de pessoas, o equivalente a 9\% dos postos de trabalho, que consolidam a "indústria" do turismo como a maior geradora de emprego e renda.

Para essa condição de relevância da atividade turística na economia mundial, colaboraram os avanços tecnológicos e o maior acesso às informações,

\footnotetext{
${ }^{2}$ Mário Beni, Análise Estrutural do Turismo, pág. 39.

${ }^{3}$ Rita de Cássia Ariza da Cruz, Introdução à Geografia do Turismo, pág. 4.
} 
a globalização dos mercados, as facilidades de deslocamento e o aumento do tempo de lazer. Em função do aumento do tempo livre, considera-se que o turismo ocupa um papel cada vez mais importante na sociedade, passando a constituir-se mesmo em uma necessidade na vida das pessoas.

Desse modo, conforme Reinaldo Dias, ${ }^{4}$ o uso do tempo livre no turismo seria uma oportunidade para que o indivíduo livre dos deveres cotidianos e obrigações profissionais viajasse não apenas à procura de descanso, divertimento e entretenimento, mas também em busca do seu desenvolvimento pessoal, sendo esta uma das funções do lazer.

"as viagens turísticas estão em plena expansão e expressam de modo bastante forte uma necessidade de evasão" e preenchem outras necessidades, entre as quais a função de desenvolvimento da personalidade, em todos os seus aspectos, em particular, do ponto de vista espiritual.

(Dias, 2003, p.12)

Mais que um tempo para distração, o turismo é uma oportunidade para o reencontro e o diálogo, do homem com o homem e deste com o universo, um momento de serenidade cuja dimensão espiritual é definida por Montejano (1999, p.78), conforme Dias:

o turismo contribui para o desenvolvimento dos valores espirituais e deve ser considerado como um fator de restauração da personalidade e dignidade humana. Graças ao turismo, corpo e espírito humano se restabelecem da fadiga do trabalho e ritmo cotidiano da vida.

(apud Dias, 2003, p.13)

Ao dedicar o tempo livre ao desenvolvimento do seu lado espiritual, às reflexões sobre o significado da vida, à busca de si mesmo, o indivíduo estaria à procura de um encontro com o sagrado. Assim, o tempo livre contribui para

\footnotetext{
${ }^{4}$ Reinaldo Dias, O Turismo Religioso como Segmento do Mercado Turístico, pág. 12 - Turismo Religioso, ensaios e reflexões.
} 
"intensificar as várias formas de nossa vida espiritual e, num certo sentido, fortalece-a e desenvolve-a" (Vukonic, 1926, citado em Dias, 2003, pág. 12). Na afirmação do próprio Dias, ${ }^{5}$ "a busca da identidade, conhecer-se a si mesmo, a razão de ser do turismo, encontra sua mais forte expressão no turismo religioso".

A seguir, este trabalho tratará de conceituar os vários tipos de turismo religioso, hoje subdividido em outras classificações de forma a atender à segmentação da demanda turística, e de estabelecer sua vinculação ao evento em que se comemora o aniversário do sonho-visão de Dom Bosco.

\subsection{O Turismo Religioso}

Desde 1979, por sugestão da Organização das Nações Unidas, as motivações das viagens turísticas começaram a ser classificadas e ordenadas com base nas estatísticas do turismo internacional para que os destinos pudessem trabalhar no planejamento, promoção e comercialização de seus produtos.

De acordo com a Organização Mundial do Turismo, a motivação religião/peregrinação está entre os principais motivos das viagens turísticas. Atrás do turismo de férias e do turismo de negócios, o turismo religioso é um dos que mais cresce em todo o mundo.

Embora alguns autores ainda não considerem a demanda pelo turismo religioso em seus estudos, Mário Beni defende a sua inclusão entre os segmentos atrativos da demanda turística, uma vez que os "peregrinos assumem um comportamento de consumo turístico, pois utilizam equipamentos e serviços com uma estrutura de gastos semelhante à dos turistas reais". Para o autor, turismo religioso "refere-se ao grande deslocamento de peregrinos, portanto turistas

\footnotetext{
${ }^{5}$ Reinaldo Dias, O Turismo Religioso como Segmento do Mercado Turístico, pág. 12 - Turismo Religioso, ensaios e reflexões.
} 
potenciais, que se destinam a centros religiosos, motivados pela fé em distintas crenças". 6

Para a socióloga Deis Siqueira, o termo religioso estaria vinculado aos "dogmas, hierarquias, estruturas, templos, rituais, sacerdócio" de uma religião e hoje expande-se para incluir "tudo aquilo em que cada um acreditar", sem as amarras institucionais da Igreja. ${ }^{7}$

Ao conceituar o turismo religioso, Dias afirma que a motivação principal para a viagem é de ordem religiosa, mas outras motivações podem ocorrer, como curiosidade ou interesse cultural pela manifestação em si. Não importa a motivação, "os viajantes fazem uso dos mesmos equipamentos, transportes e são gerados produtos para atender suas expectativas", justifica.

Turismo religioso é aquele empreendido por pessoas que se deslocam por motivações religiosas e/ou para participação em eventos de caráter religioso. Compreende romarias, peregrinações e visitação a espaços, festas, espetáculos e atividades religiosas.

(Dias, 2003, p.17)

Em pesquisa realizada sobre Turismo Místico, Religioso e Espiritual em Brasília, para a Secretaria de Turismo do Distrito Federal, o coordenador do turismo místico no DF, José Roberto Bezerra Mariano, define turismo religioso como um segmento

diretamente relacionado com a religião da pessoa. Os turistas deste segmento são os fieis que manifestam sua fé mediante visitas aos locais simbólicos de sua religião, participando de celebrações, festas santas e romarias, comemoradas em datas pré-definidas. Realizam também visitas aos lugares santos para fazer promessas e pagar suas penitências.

\footnotetext{
${ }^{6}$ Mário Beni, Análise Estrutural do Turismo, pág. 422.

${ }^{7}$ Deis Siqueira, As novas religiosidades no Ocidente - Brasília, cidade mística, pág. 17.
} 
(Setur, 2003)

Dias classificou em seis tipos os atrativos turísticos religiosos que podem servir de motivação ao turismo religioso. São eles:

1. Santuários de peregrinação

2. Espaços religiosos de grande significado histórico-cultural

3. Encontros e celebrações de caráter religioso

4. Festas e comemorações em dias específicos

5. Espetáculos artísticos de cunho religioso

6. Roteiros de fé

No Brasil, onde predomina a fé católica (74\%), é possível encontrar exemplos de cada um desses atrativos turísticos-religiosos em várias partes do país, como a Basílica de Aparecida, em São Paulo, o maior santuário religioso do país, com sete milhões de visitantes ao ano, os encontros de fiéis que lotam ginásios e estádios, especialmente, no período do carnaval, a Festa do Divino, em Goiás, a Lavagem do Bonfim, na Bahia, o Círio de Nazaré, em Belém, a encenação da Paixão de Cristo, no interior de Pernambuco, dentre outros roteiros de expressão religiosa.

Em toda a história da humanidade há exemplos de deslocamentos contínuos de pessoas com finalidade religiosa. Dentre os destinos mais procurados em todo o mundo ocidental, os mais famosos são Fátima, em Portugal, Lourdes, na França, e Santiago de Compostela, na Espanha. No Brasil, há vários exemplos de centros de peregrinação. Um dos mais conhecidos é o município cearense de Juazeiro do Norte, onde está sepultado Padre Cícero, padrinho de muitos nordestinos.

A Embratur - Empresa Brasileira de Turismo catalogou os 50 principais roteiros da fé católica no Brasil, ${ }^{8}$ onde são elencados os mais procurados destinos em que se realizam celebrações religiosas e romarias dos devotos de santos católicos. Segundo dados da instituição, todos os anos 15 milhões de fiéis se

${ }^{8}$ Embratur, Turismo Religioso - Roteiros da Fé Católica no Brasil 
deslocam pelo país para participar de eventos religiosos (Embratur, 2002). São peregrinos que pedem graças, pagam promessas e... fazem turismo.

Com base nas pesquisas e informações reunidas neste trabalho, acredita-se que Brasília poderá se transformar também em um centro de atração para turistas-religiosos que se deslocariam para a capital do país a fim de celebrar a profecia da Terra Prometida, no aniversário do sonho-visão de Dom Bosco.

Segundo a Conferência Mundial de Roma, realizada em 1960, o turismo religioso é uma atividade que movimenta peregrinos em viagens pelos mistérios da fé ou da devoção a algum santo. Para o cardeal Dom Eugênio Sales, arcebispo do Rio de Janeiro, o "turismo religioso não é propriamente uma excursão nem um passeio, mas uma viagem inspirada pela fé, que toma o nome de peregrinação" (Embratur, 2002).

A peregrinação é considerada "uma forma de viagem perfeitamente relacionada com o turismo", argumenta Dias, ${ }^{9}$ baseado no fato de que "o comportamento de peregrinos e turistas é semelhante" e, em sua maioria, fazem uso dos mesmos equipamentos e serviços. MacCannell (1973, citado em Dias, 2003, p.23) procurou demonstrar que "a peregrinação não só é um antecedente do turismo, mas o turismo é uma forma atual de peregrinação".

A peregrinação pode ser realizada em grupo ou individualmente. Essa característica é que a torna diferente de romaria, descreve Dias:

no Brasil, o termo romaria está mais relacionado ao caráter coletivo da viagem, sendo o romeiro o membro da comunidade que faz a jornada religiosa comum. A palavra peregrino tem sido mais associada com a experiência individual vivida pelo que faz a jornada.

\footnotetext{
${ }^{9}$ Reinaldo Dias, O Turismo Religioso como Segmento do Mercado Turístico, pág. 19 - Turismo Religioso, ensaios e reflexões.
} 
Para o peregrino, o deslocamento ao santuário ocorre devido estritamente à sua espiritualidade, vai à busca de um aperfeiçoamento, cumprir votos feitos anteriormente, pagar uma promessa, agradecer uma benção, o reconhecimento de uma graça recebida, a participação em uma festa religiosa importante etc.

(Dias, 2003, p. 22)

A espiritualidade que move o peregrino na sua jornada individual ou coletiva transcende o conceito de turismo religioso, vinculado a uma religião. $O$ sincretismo religioso dos tempos atuais, onde se misturam diferentes cultos ou doutrinas religiosas levou a uma subclassificação do turismo religioso e hoje já se convencionou falar em turismo místico, esotérico e espiritual.

No caso do evento Aniversário do Sonho-Visão de Dom Bosco, objeto deste estudo, fica claro o conceito de transcendência do evento, que por natureza é religioso, mas é também místico e espiritual, como se verá adiante.

\subsection{O Turismo Místico e Esotérico}

A profecia da Terra Prometida que justifica o evento em que é celebrado o Aniversário do Sonho-Visão de Dom Bosco é, por si, um elemento místico baseado na crença dos sinais divinos, da visão, da profecia, do mistério e do sagrado. A este ponto de partida, que é, na sua essência, místico, associa-se o sentido religioso de celebração do Santo.

O místico está hoje associado às novas formas de religiosidade que se observa surgir no mundo contemporâneo. Para Germiniani, ${ }^{10}$ elas se molduram a partir de duas tendências. A primeira, ainda marcada pela fidelidade aos dogmas de uma igreja e, a outra, expressa pela pluralidade de novas práticas religiosas.

\footnotetext{
${ }^{10}$ Haudrey Germiniani, "Turismo Religioso”: A Relação entre Religião e Consumo na Sociedade Contemporânea, pág. 122.
} 
Em O Livro das Religiões, Hellern, Notaker e Gaarder constatam que a característica típica das novas tendências religiosas é o sincretismo, ou seja, a presença de elementos de várias religiões. Além de se considerarem "universais e aplicáveis a todos", esses movimentos vêem a si mesmos como "a religião das religiões", "a revelação final, a resposta última, a verdade plena e completa". ${ }^{11}$

Outro traço comum às novas religiosidades, segundo os autores, é a relevância dada à experiência interior, mais importante que o dogma ou ritos. Em outras palavras, "o indivíduo pode encontrar a si mesmo". ${ }^{12}$

Hellern, Notaker e Gaarder descrevem como experiência mística a "sensação direta de ser um só com Deus ou com o espírito do universo". Segundo eles, o místico deve percorrer "o caminho da purificação e da iluminação" até seu encontro com Deus. ${ }^{13}$

Misticismo, segundo o Dicionário Houaiss (2002), é a “inclinação para acreditar em forças e entes sobrenaturais e preocupar-se com eles, em detrimento das explicações racionais e científicas". Ou, ainda, é a "crença de que o ser humano pode comunicar-se diretamente com a divindade ou receber dela sinais ou mensagens".

De acordo com Siqueira, ${ }^{14}$ o misticismo é definido como "a atitude humana que visa a união das pessoas com as forças sagradas, transcendentais, o mistério fascinante" e "nasce do esforço que a pessoa faz para alcançar uma realidade divina".

\footnotetext{
${ }^{11}$ Victor Hellern, Henry Notaker e Jostein Gaarder, O Livro das Religiões, pág. 256.

${ }^{12}$ Id. Ibid., pág. 256.

${ }^{13}$ Id. Ibid., pág. 33.

${ }^{14}$ Deis Siqueira, As Novas Religiosidades no Ocidente - Brasília, cidade mística, pág. 16.
} 
Tendências místicas podem ser encontradas em todas as grandes religiões do mundo e vários autores, na própria definição de turismo religioso, já mencionavam a presença dessa dimensão mística, como lembra Silveira. ${ }^{15}$

Andrade (2000) define "turismo religioso" como um conjunto de atividades que, a partir das visitas a localidades "religiosas" utilizando parcial ou totalmente determinados equipamentos, procura expressar sentimentos místicos, como fé, esperança e caridade nos adeptos/simpatizantes de qualquer religião.

(apud Silveira, 2003, p.59)

Os elementos de diversidade e pluralidade típicos das novas religiosidades também se encontram presente, de certa forma, no contexto avaliado como puramente religioso. A propósito, Dias lembra que mesmo naquele que se considera como sendo turismo religioso, o consumo de souvenirs ou lembranças de imagens de santos ou santuários como objetos de devoção traz agregado o elemento místico-espiritual. ${ }^{16}$

As práticas consideradas místicas incluem curandeirismo, geomancia, cartomancia e astrologia, resgatadas das sociedades pré-industriais, e, ainda, outras, derivadas de culturas orientais, introduzidas recentemente na cultura ocidental, como Tantra, I-Ching, cartas do Tarô e Reiki. Essas práticas, conforme Siqueira, têm sido disseminadas, principalmente, por meio da literatura esotérica. ${ }^{17}$

O esoterismo, segundo Antônio Houaiss (2002), seria o conhecimento baseado em fenômenos sobrenaturais repassado a um pequeno número de iniciados. "Trata-se de ensinamentos secretos que se transmitem em cadeias de mestres e de discípulos e acessível àqueles que são moral e intelectualmente preparados", explica Siqueira. $^{18}$

\footnotetext{
${ }^{15}$ Emerson José Sena da Silveira, “Turismo Religioso”, Mercado e Pós-Modernidade, pág. 59 Turismo Religioso, ensaios e reflexões.

${ }^{16}$ Reinaldo Dias, O Turismo Religioso como Segmento do Mercado Turístico, pág. 36 - Turismo Religioso, ensaios e reflexões.

${ }^{17}$ Deis Siqueira, As Novas Religiosidades no Ocidente - Brasília, cidade mística, pág. 35.

${ }^{18}$ Id., Ibid. pág. 16.
} 
De acordo com Hellern, Notaker e Gaarder o esoterismo está longe de ser um fenômeno novo, vem desde a Antiguidade, passando pela Idade Média, até os dias atuais. ${ }^{19}$ Para eles,

Esoterismo é um termo quase tão abrangente quanto religião. Ele engloba astrologia, espiritismo, ufologia, parapsicologia, várias formas de magia e clarividência, teosofia e antroposofia.

(Hellern, Notaker e Gaarder, 2000, p.257)

Místicos-esotéricos é o termo encontrado por Siqueira, ${ }^{20}$ "na falta de conceito melhor", para definir os grupos das novas religiosidades, "caracterizadas pelo trânsito dos adeptos, dos valores, dos símbolos, dos rituais" e de uma postura ecumênica diante das diferentes religiões e religiosidades.

As novas religiosidades se caracterizam, entre outros elementos, sobretudo, por um bricolage de várias crenças, rituais, práticas. Ademais, há um grande trânsito entre os diferentes grupos ou religiosidades, e o ecumenismo é um valor comum em todos ou quase todos. Assim, na falta de um conceito melhor, utilizo o de grupos místicos-esotéricos. Isso porque a experiência místico-esotérica é considerada como mais importante do que os dogmas, as verdades sacramentais, os rituais prontos. A experiência pessoal, centrada no autoconhecimento, mais mística ou mais esotérica, é fundamental.

(Siqueira, 2003, p.25)

As tendências místico-esotéricas não estão estabelecidas como igreja, nem seita. E seus líderes são, simultaneamente, escritores, conferencistas e, principalmente, terapeutas que atuam em Brasília e na região do Entorno da

\footnotetext{
${ }^{19}$ Victor Hellern, Henry Notaker e Jostein Gaarder, O Livro das Religiões, pág. 258.

${ }^{20}$ Deis Siqueira, As Novas Religiosidades no Ocidente - Brasília, cidade mística, pág. 21.
} 
capital. Objetiva-se uma religiosidade como estilo de vida. Busca-se "ficar ou estar Zen" no cotidiano. ${ }^{21}$

O místico-esotérico integra-se a um mercado de terapias (cura astral, aplicação de reiki, iridologia, florais, homeopatia), massagens (do-in, ayurvédica, shiatsu), práticas e técnicas de auto-ajuda, de relaxamento, de harmonização dos chakras, de energização, de meditação, acupuntura, yoga, tai-chi-chuan, astrologia e mapa astral, sessões xamânicas para homens, rituais da lua cheia para mulheres, leituras de tarô, de l-Ching e de runas, objetos (cristais, pedras específicas segundo o signo e o ascendente, duendes).

Com muito incenso e meditação, as pessoas movem-se em torno de uma literatura específica de como contatar seu anjo, de como ter sucesso espiritual. Os freqüentadores ou adeptos dos grupos místico-esotéricos são um público, mais ou menos religioso, consumidor de práticas e de produtos alternativos, buscam o holístico e melhor qualidade de vida.

(Siqueira, 1998, p. 21)

Embora haja uma tendência de estabelecer-se uma definição comum para o que seja turismo místico e turismo esotérico, a própria Siqueira tratou de fixar as diferenças entre uma e outra experiência.

na experiência mística, o divino "desce" ao homem, ao passo que no processo esotérico toda a iniciativa advém dos esforços do homem. O místico teria então um caráter mais passivo, enquanto o esotérico, um caráter mais ativo.

(idem, 2003, p.17)

Assim, a crença do homem na profecia da Terra Prometida tem na sua natureza um elemento místico ou esotérico que liga o homem ao divino e dá ao evento em que se comemora o Aniversário do Sonho-Visão de Dom Bosco, uma

${ }^{21}$ Deis Siqueira, Práticas místicas e esotéricas na capital do Brasil, p. 21. 
conotação mística, que associada às características de misticismo que cercam a capital do país, contribuem para a formatação de um evento com forte atrativo turístico tanto do ponto de vista religioso como místico.

\subsection{O Turismo Espiritual}

Trata-se agora de estabelecer o elemento de ligação da profecia de Dom Bosco com o turismo espiritual. A Terra Prometida, onde jorrará leite e mel, e de onde se espera venha a nascer uma nova civilização, já é ponto de referência para aqueles que associam Brasília à capital do Terceiro Milênio e para a região do Planalto se deslocam em busca de um encontro com a espiritualidade.

Antes, porém, faz-se necessário, conceituar o turismo espiritual, uma classificação que surge entre alguns autores, embora ainda timidamente, para definir as experiências religiosas dos peregrinos na sua busca interior.

Jefferson Gazoni fala em viagem espiritual dos peregrinos, ao estudar o desenvolvimento do turismo nos espaços mítico-religiosos, a partir do evento Os Passos de Anchieta, realizado anualmente no litoral do Espírito Santo para marcar a passagem do padre José de Anchieta pela costa capixaba. ${ }^{22}$

Em Os Passos de Anchieta, percebe-se que o atrativo aparente das tradições, marcos arquitetônicos histórico-culturais, vivência social do caminho, áreas naturais etc., não passam de pretextos para esta busca interior à procura do EU.

(Gazoni, 2003, p.114)

Em ensaio onde analisa a relação entre turismo, religião e consumo, Germiniani faz referência expressa ao turismo espiritual e, mais à frente, sugere que "o turismo religioso estaria apontando para a emergência de uma nova forma 22 Jefferson Gazoni, Aproveitamento Turístico de Recursos Mítico-Religiosos: os Passos de
Anchieta, pág. 114 - Turismo Religioso, ensaios e reflexões. 
religiosa, ou de espiritualidade", onde mesmo o consumo de "bens espirituais" é aceito como uma coisa positiva. ${ }^{23}$

Ao conceituar o turismo espiritual, o coordenador do turismo místico no DF, José Roberto Bezerra Mariano, afirma que

Esse segmento transcende as crenças e religiões estando ligado ao Ecumenismo e à busca do autoconhecimento. Porém, é possível trabalhar os dois segmentos (místico e espiritual) no mesmo destino. No segmento espiritual, o turista-peregrino pode não ter religião alguma, mas respeita todas as religiões, pois sabe que Deus está presente em todas elas. Os peregrinos deste segmento caminham em busca de harmonia com o meio ambiente, procurando preservar e divulgar o patrimônio e a memória dos acontecimentos.

(Setur, 2003)

Espiritual é "relativo a religião, a misticismo, a crenças; sobrenatural, místico", define Houaiss, colocando tudo no mesmo caldeirão semântico. E completa, é "tudo que não é material; o que é próprio do espírito, da alma, ou da religião". Mas, ao conceituar o termo espiritualismo, Houaiss joga luz sobre o significado do vocábulo, segundo ele, uma

teoria que, supondo a realidade autônoma e condicionante da alma em relação ao corpo, afirma a superioridade moral dos valores nascidos no espírito sobre as inclinações e desejos materiais

(Houaiss, 2002)

De fato, naqueles que Hellern, Notaker e Gaarder preferiram chamar de movimentos alternativos "há uma profunda descrença do materialismo. Trata-se de uma reação ao ponto de vista materialista e também à ciência aplicada, que

\footnotetext{
${ }^{23}$ Haudrey Germiniani, "Turismo Religioso": A Relação entre Religião e Consumo na Sociedade Contemporânea, pág. 124 - Turismo Religioso, ensaios e reflexões.
} 
levou ao acúmulo de armas atômicas e à ameaça ambiental para a vida na Terra". 24

Dá-se ênfase a valores espirituais mais profundos, muitos inspirados pela filosofia oriental. Mais e mais pessoas estão se voltando para o carma e a reencarnação ou para a interação entre yin e yang, de maneira totalmente independente de sua formação religiosa. Da mesma forma, o interesse pela meditação e pela ioga cresceu bastante nas últimas décadas - mais ou menos isoladas de seu próprio contexto religioso. Os astrólogos crêem que estamos rumando para uma "nova era" (a Era de Aquário), a qual se caracterizará por uma orientação mais espiritual. Tais idéias, originalmente enraizadas num contexto religioso, permitem-nos falar de uma nova "espiritualidade universal".

(Hellern, Notaker e Gaarder, 2000, p.261)

Ainda de acordo com Hellern, Notaker e Gaarder, ${ }^{25}$ os movimentos alternativos "não apenas se preocupam em alterar nossa maneira de pensar, mas se empenham também na implantação de um novo estilo de vida". Assim, eles manifestam-se também na área da medicina e saúde pregando a homeopatia ou naturopatia, a acupuntura, curas espirituais, análise da aura, bem como parapsicologia, telepatia, clarividência, levitação ou telecinesia (movimento de objetos físicos pela energia psíquica).

Estabelece-se a crença de que "a nova mentalidade científica será caracterizada pelo holismo (da palavra grega holos, "total", "inteiro") - o ser como um todo, onde o todo afeta as partes". Dessa forma, "cada órgão dentro do corpo é influenciado pelo indivíduo como um todo; o indivíduo é parte de um sistema ecológico, e nosso planeta tem uma relação orgânica com o resto do universo". ${ }^{26}$

Pelo que se observa a partir do estudo dos vários autores é que todos esses novos elementos sejam religiosos, místicos, esotéricos ou espirituais podem ser

\footnotetext{
${ }^{24}$ Victor Hellern, Henry Notaker e Jostein Gaarder, O Livro das Religiões, pág. 260.

${ }^{25}$ Id. Ibid, pág. 262.

${ }^{26}$ Id. Ibid., pág. 262.
} 
classificados no conceito de religiosidade, das novas tendências religiosas, que se convencionou chamar sincretismo, ecumenismo, novas religiosidades ou movimentos alternativos religiosos.

Embora seja possível constatar que os elementos místicos estejam presentes no religioso, bem como os esotéricos no místico e os espirituais permeando todos eles, as sutis diferenças entre um e outro têm levado a uma estratificação do turismo, ao surgimento de novos segmentos como uma necessidade para atender à demanda de grupos específicos. Dessa forma, é possível falar em turismo religioso, turismo místico e turismo espiritual.

Enquanto o turismo religioso estaria mais associado ao conceito clássico de religião, vinculado aos dogmas e ritos de uma Igreja, o turismo místico apresentase mais relacionado às experiências mágicas, ao sobrenatural agindo sobre o homem, e o turismo espiritual desponta como a busca do autoconhecimento, do Eu interior, acima dos valores materiais.

Se no aspecto religioso, místico e espiritual todos têm em comum o sentimento de fé que move seus seguidores, no campo turístico, os peregrinosturistas ou turistas religiosos manifestam também a demanda por infra-estruturas e serviços e, em maior ou menor grau, comportam-se como consumidores ao adquirirem produtos ou "bens simbólicos" associados ao evento ou ao lugar, trazendo benefícios para a comunidade.

Desse modo, os eventos religiosos, na concepção geral, tendem a uma postura de aceitação e tolerância quanto às motivações dos participantes, a uma convivência pacífica entre o sagrado e o profano e à incorporação do turista consumidor, seja ele peregrino ou não.

No caso específico do evento Aniversário do Sonho-Visão de Dom Bosco, objeto deste estudo, é possível determinar a presença da fé e dos rituais da Igreja Católica, o sagrado (missa e procissão) e o profano (shows de rock, consumo), mas também o místico, o esotérico, sobrenatural, na visão profética e no mito do sonho. E, por fim, acrescente-se o espiritual como a busca do homem pelo seu 
EU, a jornada interior, na crença da Terra Prometida, da espiritualidade, de uma nova consciência, do paraíso onde jorrará leite e mel. 


\section{O TURISMO EM BRASÍLIA}

O principal indicador dos fluxos turísticos internos aponta Brasília como a segunda cidade do país em movimentação de passageiros nos aeroportos. Perde apenas para São Paulo na contabilidade das pessoas que embarcam e desembarcam de seus aeroportos. Segundo dados do Anuário Estatístico da Embratur (2002, vol.30), cerca de 3,3 milhões de pessoas passaram pelo Aeroporto Internacional JK, em 2002, contra 4,6 milhões no Rio e 9,5 milhões em São Paulo.

Embora sejam números significativos, eles não representam de fato um movimento turístico efetivo. Trata-se de pessoas que se destinam à capital federal a trabalho ou a negócios, principalmente de terça a quinta-feira. Nos finais de semana, o fluxo de pessoas que visitam a capital diminui sensivelmente e a taxa de ocupação nos hotéis da cidade cai para cerca de 30 por cento.

De acordo com dados da Embratur, Brasília está em $14^{\circ}$ lugar entre os destinos turísticos mais visitados do país. No entanto, são muitas as possibilidades que se abrem para incrementar o desenvolvimento do turismo na capital do país. Entre elas, o turismo de eventos, o turismo cívico, o turismo rural, o ecoturismo e o turismo místico e religioso. Em todas essas vertentes do turismo, Brasília apresenta potencial para consolidar roteiros que atraiam não apenas os visitantes internos como também os do exterior.

A capital brasileira, construída por JK e planejada por Niemeyer e Lúcio Costa, já conquistou o mundo com sua imagem de cidade moderna, de arquitetura arrojada, com grandes espaços verdes e um céu esplendoroso. Não por acaso, a cidade foi declarada pela Unesco como Patrimônio Cultural da Humanidade. Essas características privilegiadas e trabalhadas no contexto de um projeto turístico podem transformar Brasília num grande pólo de atração para estudantes e profissionais de arquitetura de todas as partes do mundo, assim como se constituem num diferencial na disputa para ser a sede de grandes eventos ligados ao tema. 
Estrategicamente localizada no centro geográfico do país, sede do poder decisório nacional, a cidade apresenta como uma de suas principais vocações o turismo de eventos. A facilidade de deslocamentos, o setor hoteleiro central com mais de 13 mil leitos, o moderno Aeroporto Internacional JK, a apenas $15 \mathrm{~km}$ do centro urbano, restaurantes sofisticados e representativos da culinária regional de todo o país, o pavilhão Expo-Brasília, o segundo maior do país, com 58 mil metros quadrados, o Centro de Convenções Ulysses Guimarães, que a partir da reforma terá a capacidade ampliada para mais de sete mil lugares, e os novos centros que estão surgindo, dão a Brasília vantagens excepcionais para a captação de eventos de grande porte.

Igualmente, o turismo cívico destaca-se como uma forte vocação de Brasília a ser trabalhada. Os palácios, museus e monumentos guardam a recente história do país. Além disso, não se pode ignorar o fato de que a cidade possui uma característica única, a de ser a capital de todos os brasileiros, um dado importante quando se trata de vender o produto Brasília.

O turismo rural, por sua vez, já provou a força do seu segmento no Distrito Federal, onde houve um aumento considerável de empresas nos últimos anos explorando o setor. Chácaras de lazer, restaurantes rurais, pesque-pagues, pequenas pousadas e muitas outras atrações campestres conquistaram os brasilienses nos finais de semana. É um segmento voltado para o mercado interno, mas que ainda tem muito a crescer.

O ecoturismo na região do Cerrado goiano é uma realidade. O Parque Nacional da Chapada dos Veadeiros, o Salto do Itiquira, o Lago de Serra da Mesa, o Salto de Corumbá, a Lagoa Feia, as cachoeiras e trilhas de Pirenópolis fazem parte do roteiro da região, tendo Brasília como o grande portão de entrada para essas atrações.

Brasília desperta novamente para as potencialidades do Lago Paranoá, onde é possível desenvolver o turismo náutico. Os dados impressionam. Brasília possui 10.400 embarcações cadastradas na Delegacia Fluvial, constituindo-se na 
terceira maior frota de barcos do país (dados de 2001). É o maior número per capita de embarcações, com relação de um barco para cada oito pessoas. Embora em ritmo lento, o Projeto Orla, cuja finalização depende muito do interesse e ação da iniciativa privada, tem avançado, com a construção da Ponte JK e a revitalização das áreas de lazer no Pontão Sul e Ermida Dom Bosco.

O turismo místico é um segmento de reconhecido potencial em Brasília. O Vale do Amanhecer, o Templo da LBV, a Cidade da Paz, a Cidade Eclética, o sonho profético de Dom Bosco, os inúmeros templos religiosos, os monumentos em forma de pirâmides e as incríveis semelhanças com o Egito antigo são elementos que integram o roteiro mágico da cidade. O misticismo de Alto Paraíso, no estado de Goiás, a $284 \mathrm{~km}$ de Brasília, contribui significativamente para aumentar o fascínio daqueles que se interessam pelos mistérios do Planalto Central.

A seguir, apresenta-se um estudo sobre os elementos que configuram a manifestação do religioso, do místico e do espiritual em Brasília e de que forma contribuem para a demanda turística na capital do país.

\subsection{O Turismo Religioso, Místico e Espiritual na Capital Federal}

Brasília é hoje sede do sincretismo religioso do país. Estima-se que mais de 700 organizações religiosas, esotéricas, filosóficas, místicas e espirituais, estão representadas na capital, que abriga o maior número de templos religiosos por $\mathrm{m}^{2}$. A Catedral de Brasília, cujas formas lembram as mãos erguidas em prece, é o símbolo do ecumenismo da cidade.

Embora haja uma predominância da religião católica, novas manifestações religiosas e espirituais vêm se formando devido a uma série de fatores que atraíram para a capital, grupos de todas as regiões do país e também do exterior, com as mais diversas influências religiosas. 
Profecias e visões acompanham a cidade desde a sua criação. A mais importante delas é a do santo italiano São João Bosco, que em 1883, previu o surgimento da "terra prometida, vertendo leite e mel", entre os paralelos $15^{\circ}$ e $20^{\circ}$, onde foi construída Brasília. Para muitos videntes, a cidade é um centro irradiador de poder e energia. Os teósofos crêem que o aperfeiçoamento da humanidade na civilização de Aquarius acontecerá a partir de Brasília. Os ufólogos consideram a cidade um ponto privilegiado para a comunicação com os extraterrestres. ${ }^{27}$

A capital e o planalto central do Brasil seriam lugares diferenciados, um "laboratório vivo de experimentações, religiões e religiosidades de todas as origens, matizes, combinações". ${ }^{28}$ Brasília integra e sintetiza doutrinas, crenças e visões de mundo que nasceram na Índia, no Japão, no Tibet, no Egito, na Amazônia.

Identifica-se na região várias das características do que se chama religiosidade moderna. Uma delas é seu caráter esotérico. Assiste-se a uma série de manifestações religiosas, cada vez mais à margem das religiões institucionalizadas e inclusive contra ou em posição crítica a elas. Há recuperação de um simbolismo e de um mistério marcado por práticas mágicas (energia, vibrações, cores, cristais, pirâmides).

(Siqueira, 1998, pág. 25)

No estudo de campo realizado em Brasília, Siqueira (1998) identificou algumas vertentes no universo das novas religiosidades e as filosofias que as caracterizam.

Depois de alguns anos de pesquisa, foram identificadas várias vertentes constituintes deste universo plural: a) grupos com orientação fundamentalmente religiosa (Cúpulas de Saint Germain, Cavaleiros de Maitreya, Santo Daime, Hare Krishna etc.); b) escolas esotéricas tradicionais (Sociedade Teosófica, Sufismo, Rosa Cruz etc.); c) grupos com orientação psicológico-

${ }^{27}$ Codeplan, Guia de informações sócio-econômicas, turísticas e culturais do Distrito Federal.

${ }^{28}$ Deis Siqueira, Práticas místicas e esotéricas na capital do Brasil, p. 25. 
espiritualista (caracterizados por práticas voltadas ao desenvolvimento das potencialidades de cada um, tais como meditação, solarização, tarô, astrologia, danças, parapsicologia etc.). Os grupos são, em sua maioria, tangenciados por vários tipos de terapias espiritualizantes alternativas (Vidas Passadas, Rosa Mística etc.).

(Siqueira, 1998, pág. 5)

\subsection{Brasília Mística}

O misticismo de Brasília já correu mundo. Cada vez mais a cidade é reconhecida nacional e internacionalmente como a Capital do Misticismo e do Esoterismo, atraindo para a região inúmeros grupos religiosos, que contribuem para caracterizá-la como a capital ecumênica brasileira.

Uma aura de misticismo acompanha Brasília desde a sua criação. A cidade é considerada por muitos como a "Terra Prometida", que Dom Bosco profetizou em sonho-visão, em 1883. Há uma crença de que a região do Planalto Central, onde se inclui a capital do país e seu entorno é predestinada para ser a base da construção de uma nova civilização em um novo tempo - o Terceiro Milênio.

Essa região incluiria, ainda, a cidade de Alto Paraíso, em Goiás, a 230 km de Brasília, considerada o ckacra cardíaco do planeta. Município vizinho ao Parque Nacional Chapada dos Veadeiros, Alto Paraíso reúne um grande número de grupos místico-esotéricos, que para lá se deslocaram a partir de 1990.

Ainda, na região do entorno da capital, há duas grandes comunidades de sincretismo religioso: a Cidade Eclética, em Santo Antônio do Descoberto, onde vivem mais de 1.500 pessoas, e o Vale do Amanhecer, próximo a Planaltina, no Distrito Federal, que existe há mais de 30 anos. Há também a Cidade da Paz, que abriga a Universidade Holística Internacional de Brasília - a Unipaz. 
O misticismo que cerca Brasília ganhou força com as teorias que comparam a cidade a outra do antigo Egito, a partir de coincidências históricas e semelhanças de suas construções arquitetônicas em forma de pirâmide. A começar pelo próprio desenho do Plano Piloto, comparado ao pássaro sagrado egípcio Ibis. A sede da Companhia Energética de Brasília (CEB) é considerada por muitos, cópia fiel da pirâmide Sakara, construída na terceira dinastia do antigo Egito. Outro exemplo é o Teatro Nacional, com sua disposição irregular e apresentando 36 formas piramidais egípcias. ${ }^{29}$

O místico está presente em toda a cidade, visualizado na oferta e no consumo de bens e serviços como clínicas e institutos de terapias alternativas, cursos, restaurantes naturais, lojas e livrarias especializadas em produtos esotéricos.

A seguir, apresenta-se uma relação dos principais pontos de visitação turística ligados ao místico e esotérico.

Cidade Eclética - A cidade do líder espiritual Mestre Yokaanam, a 62 km de Brasília, tem uma população de pouco mais de 1.500 habitantes, que vive do cultivo da terra, do artesanato em couro e da criação de gado. Yokaanam pretende que a Cidade Eclética seja o centro de todas as religiões do mundo, dirigida pela Igreja Eclética Espiritualista Universal por ele fundada. Fica localizada no município de Santo Antônio do Descoberto.

Cidade da Paz - A Cidade da Paz funciona como fundação e abriga a Universidade Holística que tem como principal objetivo contribuir para o crescimento pessoal e o despertar espiritual de cada cidadão. Engloba atividades cientificas, religiosas, místicas, tecnológicas e educacionais por meio de projetos, eventos, estudos e pesquisas em todas essas áreas. Está localizada na Granja do Ipê - acesso BR-040, km 30 - estrada para o Gama.

${ }^{29}$ Codeplan, Guia de informações sócio-econômicas, turísticas e culturais do Distrito Federal. 
Universidade da Paz - A Unipaz foi criada por um movimento internacional com o objetivo de promover uma cultura de paz entre os vários segmentos sociais, introduzindo uma nova consciência e promovendo a integridade do ser, divulgando o movimento holístico.

Vale do Amanhecer - Exemplo de religiosidade esotérica, o Vale do Amanhecer é o maior e mais impressionante fenômeno de sincretismo religioso do país, onde pessoas de todas as classes sociais buscam orientação espiritual. Localiza-se em Planaltina e foi fundado, em 1969, pela sergipana Neiva Chaves Zelaya, mais conhecida como Tia Neiva, que morreu em 1985. A comunidade abriga milhares de médiuns e atende aproximadamente 50 mil pessoas por mês.

LBV - Templo da Boa Vontade - Exemplo de religiosidade sincrética, o Templo da LBV tornou-se ponto de peregrinação e visitação. São mais de duas mil pessoas por mês. O templo é composto por sete locais de visitação: a nave principal, uma pirâmide de sete faces que tem em seu ápice o maior cristal puro encontrado na região, com $40 \mathrm{~cm}$ de altura e $21 \mathrm{~kg}$. Por ser um templo ecumênico, seu altar é representado apenas pelos 4 elementos da natureza (ar, água, terra e fogo). ${ }^{30}$

\section{Eventos místicos/espirituais}

Caminhada da Lua - caminhada no Parque da Cidade, que acontece todas as noites de lua cheia, com percursos de 4, 5, 6 e $9 \mathrm{~km}$. Paralelamente são realizadas atividades culturais e de interação, tais como dança, recreação infantil, oficinas etc.

\footnotetext{
${ }^{30}$ A Legião da Boa Vontade, fundada por Alziro Zarur na década de 40 , constitui-se numa mescla de elementos católicos e espíritas, acreditando na reencarnação e na caridade como forma de atingir a perfeição e "prece" (Silveira, 2003, p.75).
} 


\subsection{Brasília Religiosa}

São centenas de festas religiosas no país acontecendo de janeiro a dezembro em todo o país. A grande maioria delas vinculada ao calendário da Igreja Católica. São exemplos, eventos tradicionais como o Natal, a Semana Santa, as celebrações do calendário litúrgico - Paixão de Cristo, Páscoa, Pentecostes, Corpus Christi, as festas regionais e nacionais para santos e padroeiras, e as juninas, que saúdam Santo Antônio, São João e São Pedro, dentre inúmeras outras.

Praticamente toda cidade brasileira tem sua igreja, seu santo padroeiro e a sua festa católica. Na capital do país não é diferente. São vários eventos religiosos já tradicionais na cidade, entre os quais se destacam: a celebração da Via Sacra, em Planaltina, na sexta-feira da Paixão, o Dia de Nossa Senhora Aparecida, padroeira de Brasília e do Brasil, no dia 12 de outubro, e o Aniversário da Visão de Dom Bosco, segundo padroeiro da cidade, no último domingo de agosto.

De acordo com o Guia de informações sócio-econômicas, turísticas e culturais do Distrito Federal, produzido pela CODEPLAN - Companhia do Desenvolvimento do Planalto Central (1999, p.188), Brasília conta hoje no campo doutrinário-religioso com dezenas de cultos e religiões, a saber:

loga, Budismo, Igreja Metodista, Igreja Ortodoxa, Seicho-noie, Mahikari, Igreja Messiânica Mundial do Brasil, Sociedade Maçônica, Hare Krishna, Mórmons, Ponte para Liberdade, Summit light-house, Ordem dos 49, Orion, além das religiões e seitas existem no Distrito Federal, os movimentos de busca espiritual como a Universidade Holística Internacional de Brasília, Cidade da Paz, Sociedade Brasileira de Eubiose, Centro de Estudos Gnósticos, a Sociedade Teosófica, a Rosa Cruz, A Grande Fraternidade Universal (GFU), Augusta Grande Fraternidade Universal (AGFU) e a Escola de loga de Brasília. Igreja Confissão Lutherana do Brasil, Igreja Episcopal, Igreja Presbiteriana, Igreja 
Adventista do 7. Dia, Testemunhas de Jeová, Igreja Evangélica Pentecostal, Igreja Evangélica Assembléia de Deus, Igreja Católica Apostólica Brasileira, Igreja Católica Apostólica Romana, Centros Espíritas e Casas de Umbanda e Candomblé, Igreja Universal do Reino de Deus, Igreja de Cristo, Igreja Memorial Batista, entre outras.

(Codeplan, 1999)

\subsubsection{Eventos Religiosos na capital do país}

Os eventos religiosos que acontecem tradicionalmente em Brasília são os seguintes, conforme o Guia da Codeplan:

Aniversário da Visão de Dom Bosco - Homenagem a Dom Bosco, padre salesiano da cidade de Turim, Itália, que em 1883 previu o surgimento de uma nova civilização entre os paralelos $15^{\circ}$ e $20^{\circ}$. As comemorações constam de gincanas, carreatas e cortejo náutico, com prêmios para os barcos vencedores nas categorias de animação, beleza e originalidade. A festa inicia-se com a missa campal e encerra-se com a chegada, a bênção das embarcações e a queima de fogos de artifício. Último domingo de agosto. Ermida Dom Bosco, Estrada Parque Dom Bosco, Lago Sul.

Via-Sacra ao Vivo - Encenações da paixão, morte e ressurreição de Cristo. Inicia-se no Domingo de Ramos, com representação da entrada de Jesus em Jerusalém, missa e bênção dos ramos. Na Quinta-feira Santa há a encenação da Ceia do Senhor, seguida de missa e procissão. A Via-Sacra ao Vivo é realizada na Sexta-feira Santa, no morro da Capelinha, onde são encenadas as 15 Estações Via Crucis, culminando com a ressurreição de Cristo. No Domingo da Ressurreição realiza-se a Procissão da Alvorada, às cinco horas da manhã, encerrando-se com a missa solene de Páscoa, na Igreja Matriz de Planaltina. Morro da Capelinha, Planaltina. 
Dia da Padroeira de Brasília - Homenagem a Nossa Senhora Aparecida, com procissão pela Esplanada dos Ministérios e missa solene na Catedral Metropolitana de Brasília. Dia 12 de outubro. Esplanada dos Ministérios.

Corpus Christi - Procissão pela Esplanada dos Ministérios, que se realiza após a missa solene celebrada ao ar livre, em área próxima à Catedral Metropolitana de Brasília, com a participação de aproximadamente quatro mil pessoas. Os fiéis confeccionam símbolos litúrgicos com flores e serragens, formando um longo tapete por onde passa o Santíssimo Sacramento. Quarenta dias após a Páscoa. Esplanada dos Ministérios.

Folia do Divino em Planaltina - É a festa tradicional mais esperada pela população, celebrada no sétimo domingo depois da Páscoa. As novenas são realizadas paralelamente aos leilões, às apresentações de banda de música e à reza de terços e ladainhas. No último dia de novenas, é festejada a "Folia do Divino", também chamada de "Folia de Rua". Às primeiras horas da manhã, ouvem-se os foguetes, o repicar de sinos e as bandas de música, com a participação do povo, que assiste à saída da folia da igreja matriz. A população acompanha o folião de rua, que vai na frente carregando a bandeira do Divino Espírito Santo. Enquanto a banda toca, o povo entoa cânticos tradicionais. O café matinal é servido numa barraca armada em frente a casa do folião, e, em seguida, a folia percorre todas as ruas da cidade. Além do folião, há também o "imperador", escolhido por sorteio um ano antes da festa. No sábado à noite, queima-se uma grande fogueira e ergue-se o mastro com bandeira e a efígie da pomba, representando o Espírito Santo. Nessa festa, dança-se a catira ou cateretê, bem como a curraleira.

Festa do Divino Espírito Santo - Festa popular e folclórica tradicional de quase todas as cidades goianas, desde o século XIX. Os festejos são iniciados com novena e missa, encerrando-se com almoço oferecido aos fiéis e devotos na casa do Imperador do Divino, membro da comunidade, eleito anualmente. Sétimo domingo após a Páscoa. Brazlândia. 
Folia de Santo Reis - Festa popular iniciada pela família Rocha, de Formosa. Três grupos de homens reúnem-se na Rua Palha e saem cantando louvores aos Santos Reis com bandeiras e imagens. À frente dos grupos, um homem desfila com a vestimenta característica de um Rei Mago, ao som de violas, sanfonas e pandeiros. Nas visitas às casas, recolhem doações destinadas a um banquete oferecido aos pobres na residência do festeiro dos Reis Magos, escolhido em sorteio entre os habitantes da Rua Palha. Entre a véspera de Natal e 6 de janeiro. Planaltina.

Folia de Reis - Promovida por um grupo de 11 pessoas que saem a cavalo levando as imagens dos Reis Magos pela região, cantando e tocando. Em cada parada realiza-se um baile, com bastante comida e bebida, quando são convidadas as pessoas das demais regiões, especialmente as mais pobres. Entre a véspera do Natal e 6 de janeiro. Brazlândia.

Círio de Nazaré em Brasília - a maior romaria religiosa do Pará é revivida em Brasília, anualmente, no segundo domingo de setembro. Os fiéis realizam uma procissão com a Santa, nas proximidades da Igreja de Nazaré, na QI 3, Lago Sul. Ao término da cerimônia, é armado um arraial ao lado da igreja, onde a colônia paraense reúne-se para saborear comidas regionais.

lemanjá - Festa do Ano Novo - É o maior espetáculo da tradição religiosa afro-brasileira em Brasília. Realiza-se às margens do Lago Sul, na Prainha, onde os devotos da divindade das águas entregam suas oferendas. Com grande participação da comunidade, a festa começa com a chegada de caravanas de representantes de centros espíritas afro-brasileiros do Distrito Federal e do Entorno. Um grande show pirotécnico marca a passagem do Ano Novo. Noite de 31 de dezembro. Prainha do Lago Sul. Na noite do reveillon, os devotos de lemanjávestidos de branco levam suas oferendas (flores, velas acesas, pedidos e orações) e depositam nas águas do Lago Paranoá. 


\subsubsection{Igrejas, Templos e Comunidades Religiosas}

Ainda de acordo com o Guia da Codeplan, os principais templos religiosos localizados no Distrito Federal são:

Catedral Metropolitana Nossa Senhora Aparecida - Projetada por Oscar Niemeyer, foi inaugurada em 31 de maio de 1967. Possui 40m de altura com 16 arcos de concreto armado circundado por um espelho d'água. $\mathrm{Na}$ área externa vê-se os sinos que foram doados pelo governo espanhol batizados com o nome de Santa Maria, Nina, Pinta e Pilarica. A cruz metálica de $12 \mathrm{~m}$ de altura no topo foi benzida pelo Papa Paulo VI, doador do altar. Na entrada, os quatro evangelistas: em bronze, medindo $3 \mathrm{~m}$ de altura, de Alfredo Ceschiatti, à direita São João, à esquerda São Matheus, São Lucas e São Marcos. O interior é banhado por luz natural filtrada pelos vitrais coloridos de Marianne Peretti colocados em 1990 e lá vê-se a "Anunciação a Maria" de Athos Bulcão, a "ViaSacra" de Di Cavalcanti, a primeira réplica da "Pietá" de Michelangelo, feita de mármore e resina, pesando 600kg, doada por Paulo Xavier. Anjos suspensos no teto, de alumínio, de Ceschiatti. Abaixo do altar, réplica do Santo Sudário. Fica localizada na Esplanada dos Ministérios.

Igreja Nossa Senhora de Fátima - Igrejinha - Projetada por Oscar Niemeyer, foi o primeiro templo de alvenaria inaugurado em Brasília, em 1958. Seu formato original lembra o chapéu de uma freira. Seu exterior foi decorado com azulejos de Athos Bulcão. Por ser bem pequena, ficou conhecida como Igrejinha. Pela sua importância, a rua que a hospeda passou a se chamar Rua da Igrejinha. Fica localizada na EQS 307/308.

Templo Budista da Terra Pura - Por ser uma réplica de um templo no Japão, o de Fukui, este templo em construção tradicional foge aos padrões de modernidade de Brasília. Seu interior é todo dourado e dominado por uma estátua de Buda. Fica localizada na EQS 315/16. 
Igreja Messiânica Mundial do Brasil - Igreja de origem oriental, possui o formato de uma tumba faraônica toda em mármore branco. Fica localizada na EQN 315/16 Lt.

Catedral Santa Maria dos Militares - Rainha da Paz - Projetada por Oscar Niemeyer, localiza-se no Eixo Monumental, na altura do Setor Militar Urbano, e tem o formato de uma barraca de campana. Fica localizada no Eixo Monumental (Na altura do Setor Militar Urbano - SMU).

Mesquita Centro Islâmico do Brasil - Ocupa uma área de $2.800 \mathrm{~m}^{2}$, sendo a maior da América Latina. Construída em legítima arquitetura árabe, possui cinco blocos e um minarete (torre de onde os fiéis são chamados para as cinco orações diárias) de 37 metros de altura. Tem capacidade para 1 mil pessoas. Fica localizada na EQN 712/912.

Seicho-No-lê - O prédio apresenta a arquitetura xintoísta, crença que procura manter vivas as tradições nativas do Japão. Localizada na EQS 403/404.

Templo da Ordem Rosa-Cruz - Congrega a maior e mais antiga fraternidade do mundo. Dedica-se ao desenvolvimento do ser humano pelo poder da mente. Fica localizada na SHIN QL 6/8 trecho C - Lago Norte.

Oratório do Soldado - Destina-se a cerimônias religiosas em caráter ecumênico. Fica localizado no Setor Militar Urbano.

Igreja Adventista do $7^{\circ}$ Dia - Erguida em 1968, representa o antigo tabernáculo do povo judeu. Fica localizada na SGAS Q. 611 Mod. 75.

\subsubsection{Esculturas, Marcos e Monumentos Religiosos}

Pedra Fundamental de Brasília - Monumento em concreto, moldado com 7 metros de altura, situado no Morro do Centenário, desde 1922. Tem a forma de 
uma pirâmide, sobre base quadrada, e em uma das faces traz as placas comemorativas, fundidas no Liceu de Artes e Ofício de São Paulo. As outras partes do monumento foram moldadas em Araguari (MG), no Governo Epitácio Pessoa. A placa da base é alusiva ao tombamento da Pedra, ocorrido em 7 de setembro de 1982.

Morro da Capelinha - É hoje palco cenográfico para a Encenação da Paixão de Cristo, na Sexta-Feira Santa.

\subsubsection{Templos e monumentos em homenagem a Dom Bosco}

Ermida Dom Bosco - monumento que homenageia Dom Bosco, é um dos elementos de referência histórica e cultural mais importantes de Brasília. É o primeiro templo religioso de Brasília construído em caráter definitivo.

O projeto arquitetônico da Ermida é de Oscar Niemeyer. No interior do templo está a imagem de Dom .Bosco, esculpida em mármore de Carrara pelos irmãos Arreghini, de Pietra Santra - Itália.

A Ermida está localizada no ponto de passagem do paralelo $15^{\circ}$, referido na profecia, às margens do Lago Paranoá. Fica às margens do Lago Paranoá, após a QI 29, Lago Sul, na Estrada Parque Dom Bosco, próximo às margens do Lago Paranoá. Trata-se da primeira construção de Brasília em alvenaria. Foi concluída em 31 de dezembro de 1956 e inaugurada em 1957.

A Ermida está construída sobre uma plataforma de lajes, em uma elevação, às margens do Lago Paranoá, com sua abertura triangular voltada para a cidade, propiciando visão privilegiada de todo o Plano Piloto de Brasília, onde se destacam o Palácio da Alvorada, a Esplanada dos Ministérios e o conjunto urbano da Praça dos Três Poderes. 
Santuário Dom Bosco - Construído em homenagem ao padroeiro da cidade, seu projeto é de autoria de Carlos Alberto Naves. A fachada compõe-se de 80 colunas em concreto aparente e estilo gótico, com vitrais em 12 tonalidades de azul, que filtram a luz natural. As portas de acesso são em chapas de ferro e bronze, com motivos do sonho profético de Dom Bosco são do escultor Gianfranco Cerri. No seu interior, pende um grande lustre central, suspenso por cabos de aço, com 7.400 copos de vidro Murano e 400 lâmpadas, pesando 2.600 kg. No altar, há uma cruz de oito metros de altura, com um Cristo esculpido num único tronco pelo artista Gotfredo Thaler. A imagem encontrada à direita do altar é de N.Sra. Auxiliadora e à esquerda de Dom Bosco. Fica localizada na W3 Sul Q. 702.

Sonho de Dom Bosco - O Profeta - Escultura de Ange Falchi, em ferro e com 800 kg de peso. Está localizada na Galeria do Hotel Nacional.

Dom Bosco - Escultura dos irmãos Arreghini di Pietra Santa, de 1957. Foi esculpida em mármore de carrara, medindo 1,40 metro de altura, com base de 0,36 por 0,33 metro. Está localizada na Ermida Dom Bosco, no Lago Paranoá. 


\section{BRASÍLIA, A TERRA PROMETIDA}

Brasília sempre esteve associada a slogans como Capital do Terceiro Milênio, Capital da Esperança, Terra Prometida. Desde o início, a capital do país carrega a crença de cidade predestinada para ser o berço de uma nova civilização. Para isso, contribuíram decisivamente dois mitos vinculados à sua criação: a profecia de um santo - Dom Bosco e a obstinação de um sonhador, o seu fundador - Juscelino Kubitschek.

De acordo com o pesquisador James Holston, desde a metade do século XVIII, a idéia de transferir a capital do Brasil para o interior desabitado foi o sonho de muitos visionários, que teriam deixado a Brasília "o legado de uma mitologia do Novo Mundo em que a construção de uma capital no Planalto Central seria o meio de desencadear o florescimento de uma grande civilização num paraíso de abundância”. Um desses visionários, segundo Holston, seria o italiano João Bosco, devido à profecia da Terra Prometida. ${ }^{31}$

A profecia de João Bosco é um dentre os vários mitos de fundação oficialmente reconhecidos nos monumentos e nos livros de história da cidade. Esses mitos são versões diversas do mesmo tema: apresentam Brasília como agente civilizador do Planalto Central, como prenunciadora de um desenvolvimento invertido no qual a capital cria a civilização sobre a qual exerce uma radiosa soberania.

(Holston, 1993, págs. 23 e 24)

Sobre esses mitos, a socióloga Deis Siqueira afirma: ${ }^{32}$

Brasília nasceu a partir de dois grandes mitos de criação: a Cidade Utópica e a Terra Prometida. O primeiro está inscrito no planejamento urbano e na arquitetura futurista do Plano Piloto, que tem a forma de um avião ou de um pássaro em vôo, ou ainda

31 James Holston, A cidade modernista: uma crítica de Brasília e sua utopia, págs. 23 e 24.

${ }^{32}$ Deis Siqueira, As novas religiosidades no Ocidente - Brasília, cidade mística, pág. 39. 
de uma cruz. Os fundadores da cidade estavam imbuídos do sonho e da missão de inaugurar um novo tempo e uma nova civitas para o Brasil, ancorada no belo, na igualdade e na universalidade.

Este mito converge com um outro, místico, referenciado nas profecias de Dom Bosco, que se tornou, inclusive, o padroeiro da cidade. Coincidência ou não, estes dois mitos estão na base do fenômeno místico-esotérico que designa Brasília como a Capital do Terceiro Milênio ou da Nova Era.

(Siqueira, 2003, pág. 39)

Assim, Dom Bosco seria o profeta da nova civilização, a Terra Prometida que surgiria entre os paralelos $15^{\circ}$ e $20^{\circ}$, de onde "jorraria leite e mel", enquanto JK seria o realizador desse sonho. De acordo com Siqueira, "é fato que a profecia do Santo foi se materializando. O mito foi se tornando lenda, e esta, realidade".

$\mathrm{Na}$ pesquisa que realizou com os grupos místicos-esotéricos de Brasília, Siqueira constatou que $76 \%$ consideram a cidade predestinada, um local privilegiado no processo de preparação para o Terceiro Milênio. Segundo a socióloga, é cada vez maior o número de pessoas que chegam à região do Planalto Central, com o sentimento de construção de uma nova religiosidade, um novo estilo de vida, uma nova civilização.

Não apenas surgiram alguns grupos, juntamente com a capital, como é o caso da Cidade Eclética, do Vale do Amanhecer, e da Cidade da Fraternidade, mas o número continua a crescer, tendo sido criados, transferidos de outros locais ou fundados a partir de sonhos e de premonições de pessoas e grupos que continuam a chegar, certos de que na região se gesta uma Nova Civilização. ${ }^{33}$

(Siqueira, 2003, pág. 40)

\footnotetext{
${ }^{33}$ Deis Siqueira, As novas religiosidades no Ocidente - Brasília, cidade mística, pág. 40.
} 
A arqueóloga lara Kern, especialista em Egiptologia, defende a tese de que Brasília seria a concretização da inacabada cidade egípcia Aton, e, JK, a reencarnação de seu idealizador, o Faraó Aknaton. Ao analisar as coincidências entre a capital brasileira e a cidade egípcia, Kern afirma que "o Egito parece ser, por destino, a "Terra Prometida" dos historiadores, assim como Brasília é a "Terra Prometida" do Terceiro Milênio". ${ }^{34}$

Sem medo de errar, pela visão de D. Bosco, Brasília será o Celeiro do Mundo, de onde jorrará leite e mel. É a Capital do $3^{\circ}$ Milênio. Terá fartura e paz. E no dia que escavarem ao redor de Brasília, encontrarão desde o urânio ao petróleo. E a cultura do cerrado como disse, já começou a aflorar.

(Kern, 1995, pág.21)

Brasília parece ser, na atualidade, o mesmo imã que o Egito representou no passado. É uma cidade Cosmopolita onde afluem pessoas de todas as partes, de todos os credos em busca de trabalho, ora em busca de saber, ora pela atração vibratória, de tudo o que ela representa.

(Id. Ibid., pág. 26)

Brasília foi construída no século $X X$, como a grande programação de constituir a capital do terceiro Milênio, para receber no seu âmago, toda esta estrutura Mística, que se observa por toda parte. Ora na sua arquitetura, ora na simbologia, ora no seu próprio povo.

(Id. Ibid., pág. 66)

Entre as muitas coincidências, a egiptóloga cita a Ermida Dom Bosco, construída em homenagem ao profeta que a previu, assim como no Antigo Egito eram erguidos monumentos em homenagem aos seus fundadores.

O próprio JK, como veremos adiante, fez várias referências à profecia de Dom Bosco associando Brasília ao lugar que teria sido vislumbrado pelo Santo

${ }^{34}$ Iara Kern, De Aknaton a JK, das Pirâmides a Brasília, pág. 15. 
italiano, bem como outros personagens, aqui analisados, igualmente importantes para o resgate histórico da profecia, e que justificam a identificação de Brasília com a Terra Prometida. 


\section{A NOVA CAPITAL - A CONSTRUÇÃO DA PROFECIA}

Neste capítulo, objetiva-se resgatar um pouco da história da transferência da capital para o interior do país. Trata-se aqui de reforçar os fatos, coincidências e mistérios que ao longo da história contribuíram para construir a Brasília mitológica da Terra Prometida.

Diversas razões levaram à transferência da Capital para Brasília, entre elas a de segurança e promoção da integração nacional. A idéia de interiorização da capital do país era antiga e remonta ao Brasil Colônia, à época da Inconfidência Mineira. De acordo com o historiador e jornalista, Adirson Vasconcelos, três nomes foram fundamentais nesse processo - Tiradentes, Hipólito da Costa e José Bonifácio. ${ }^{35}$

O Alferes José Joaquim da Silva Xavier, o Tiradentes, em 1788, teria sido o primeiro a sonhar com uma capital no interior do território nacional para a República independente de Portugal que pretendia instaurar no Brasil. Mas a capital do inconfidente seria precisamente São João Del Rei, em Minas Gerais.

O jornalista Hipólito José da Costa, no jornal "Correio Braziliense", editado em Londres de 1808 a 1822, iniciou uma campanha contundente em defesa da transferência da capital do Brasil para o interior, sob o argumento da integração nacional. Citava a experiência de Washington como exemplo e definiu o futuro local da capital no Planalto Central, com a "descrição do paraíso terreal". ${ }^{36}$

José Bonifácio de Andrada e Silva fez a primeira defesa da mudança da capital para o interior em 1821, ainda no Brasil Colônia, na condição de Vicepresidente do Governo Provisório de São Paulo. Bonifácio recomendava como sendo "muito útil que se levante uma cidade central no interior do Brasil para assento da Corte ou da Regência". Ele sugeriu a região do Planalto mineiro,

\footnotetext{
${ }^{35}$ Adirson Vasconcelos, A Mudança da Capital, pág. 37.

${ }^{36}$ Id., Ibid., pág. 39.
} 
especificamente, a cidade de Paracatu para sede da nova capital, que "poderá ser na latitude pouco mais ou menos de 15 graus". ${ }^{37}$

É também, oficialmente, de José Bonifácio a primeira sugestão para o nome da futura capital - Brasília. No Brasil Império, como primeiro ministro do país já independente, encaminha à Assembléia Constituinte e Legislativa de 1823 a mensagem com a sugestão de que "esta Capital poderá chamar-se Petrópole ou Brasília".

Ao discorrer sobre a importância da trilogia - os três grandes personagens precursores da idéia de construção de uma nova capital, Vasconcelos supõe:

Coincidentemente ou por força do destino, o arquiteto, ao projetar Brasília, alevantou sua Praça principal sob a inspiração dos três pontos terminais de um triângulo, em cujos vértices estão o Poder Executivo, o Poder Legislativo e o Poder Judiciário Praça dos Três Poderes, assim como três foram os primeiros a sonhá-la e querê-la: Tiradentes, Hipólito e Bonifácio.

(Vasconcelos, 1978, pág. 45)

Outro defensor da interiorização da capital brasileira foi o diplomata, Visconde de Porto Seguro, Francisco Adolfo de Varnhagen. Segundo Vasconcelos, "o que Brasília é hoje tem muito das idéias fulgurantes e da clarividência de Varnhagen", expressas em "visão profética", no seu Memorial Orgânico de $1849 .^{38}$

Varnhagen apontou precisamente os paralelos 15 e 16 graus como a latitude mais vantajosa para a localização da futura capital, sugeriu, ainda, que deveria estar a cerca de mil metros de altitude para garantir melhor clima, na região de cerrados, nos limites das nascentes dos rios Amazonas, Prata e São Francisco, acrescentou a conveniência da cidade ficar numa chapada pouco elevada e sem muitas irregularidades, propôs a capital com uma lagoa e uma península, anteviu

\footnotetext{
${ }^{37}$ Adirson Vasconcelos, A Mudança da Capital, pág. 39.

${ }^{38}$ Id, lbid., pág. 52.
} 
que "algum dia, os mineiros "iriam" chamar a si a capital por conquista". Nessa incrível lista de acertos que viriam a se confirmar, Varnhagen só errou o nome da cidade, que seria destinada à sede do Império - Imperatória. ${ }^{39}$

Alguns autores reconhecem em outros personagens as propostas de transferência da capital para o interior do país, como a do cartógrafo genovês, Francisco Tossi Colombina, que em 1750, elaborou a Carta de Goiás e capitanias próximas, sugerindo a mudança da capital para essa região. Outro citado é o estadista português Marquês de Pombal que, em 1761, sonhava com a mudança da capital para o vale do Amazonas. ${ }^{40}$

O ideal de interiorização finalmente transforma-se em preceito constitucional, em 1889, com a Proclamação da República. No seu artigo $3^{\circ}$, a Constituição estabelecia: "Fica pertencente à União, no Planalto Central da República, uma zona de $14.400 \mathrm{~km}^{2}$, que será oportunamente demarcada, para nela estabelecerse a futura capital federal". Em cumprimento a essa determinação, o presidente Floriano Peixoto constituiu, em 1892, a Comissão Exploradora do Planalto Central do Brasil, com a finalidade de demarcar a área do futuro Distrito Federal.

A Missão Cruls, como ficou conhecida a comissão, comandada pelo astrônomo Luiz Cruls, diretor do Observatório Astronômico do Rio de Janeiro, entre os anos de 1892 e 1894 identificou e demarcou a área da futura capital, incorporando áreas de antigas fazendas das cidades goianas de Planaltina e Luziânia. A Missão definiu no Planalto Central uma área retangular - o "Quadrilátero Cruls", que recebeu, oficialmente e pela primeira vez, a expressão "Distrito Federal".

Chama a atenção, o relato feito na época pelo naturalista e botânico, $A$. Glaziou, integrante da Missão, sobre a existência no passado de um lago na área da futura capital e a sugestão para a criação de um novo lago, a partir da construção de uma barragem. ${ }^{41}$

\footnotetext{
${ }^{39}$ Francisco Adolfo de Varnhagen, A Questão da Capital: marítima ou no interior?, pág. 22.

${ }^{40}$ Fernando Oliveira Fonseca, Olhares sobre o Lago Paranoá, pág. 25.

${ }^{41}$ Id, Ibid., pág. 27.
} 
Entre os dois grandes chapadões conhecidos na localidade pelos nomes de Gama e Paranoá, existe imensa planície em parte sujeita a ser coberta pelas águas da estação chuvosa; outrora era um lago devido à junção de diferentes cursos de água formando o rio Paranauá; o excedente desse lago, atravessando uma depressão do chapadão, acabou, com o carrear dos saibros e mesmo das pedras grossas, por abrir nesse ponto uma brecha funda, de paredes quase verticais pela qual se precipitam hoje todas as águas dessas alturas. É fácil compreender que, fechando essa brecha com uma obra de arte (dique ou tapagem provida de chapeletas e cujo comprimento não excede de 500 a 600 metros, nem a elevação de 20 a 25 metros) forçosamente a água tomará ao seu lugar primitivo e formará um lago navegável em todos os sentidos, num comprimento de 20 a 25 quilômetros sobre uma largura de 16 a 18. Além da utilidade da navegação, a abundância de peixe, que não é de somenos importância, o cunho de aformoseamento que essas belas águas correntes haviam de dar à nova capital despertariam certamente a admiração de todas as nações. ${ }^{42}$

O lago, tão importante referência de localização na profecia de Dom Bosco, teria de fato existido na área da nova capital como relatou Glaziou? O fato é que, de qualquer forma, o lago nasceu mesmo antes de Brasília. Quando a construção da capital já estava sendo providenciada, uma das primeiras medidas incluía a construção da barragem que iria criar o Lago Paranoá.

No dia 7 de setembro de 1922, como parte das celebrações do Centenário da Independência do Brasil, foi lançada em Planaltina, a Pedra Fundamental da futura capital, assentada no Morro do Centenário, Serra da Independência. Em 1952, o Congresso Nacional aprovou a lei que previa a realização de estudos definitivos para a escolha de um sítio no Planalto Central, para a edificação da nova capital brasileira.

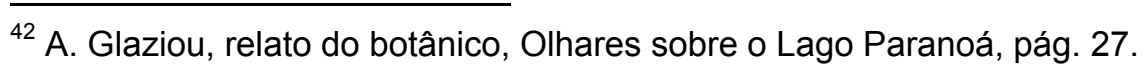


Em abril de 1955, o Sítio Castanho foi escolhido para abrigar a nova capital, exatamente no local onde esteve acampada a comitiva de Luiz Cruls, na antiga Fazenda Bananal. Em torno do local escolhido foram traçados os limites do novo Distrito Federal, com uma área de aproximadamente $5.000 \mathrm{~km}^{2}$. Ainda naquele ano, o presidente Café Filho aprovou o sítio e a área da nova capital, entre os rios Preto e Descoberto, abrangendo três municípios goianos: Planaltina, Formosa e Luziânia.

Mas seria no governo do mineiro Juscelino Kubitschek que se realizaria o ideal mudancista de interiorização da capital do país. JK acabara de fazer seu discurso como candidato à Presidência da República, em que pregara o respeito à Constituição e o respeito à lei como forma de superar os problemas políticos do país, quando o jovem goiano Antônio Carvalho Soares, coletor estadual, conhecido por Toniquinho, resolveu testar se aquelas palavras eram para valer e perguntou se caso fosse eleito mudaria a Capital para o Planalto como determinava a Constituição. Naquele 4 de abril de 1955, na cidade de Jataí (GO), nascia na resposta afirmativa de Juscelino o sonho da construção da nova capital - Brasília, transformada em meta-síntese de seu governo, e inaugurada oficialmente no dia 21 de abril de $1960 .{ }^{43}$

Quando a Constituição de 1891 determinou que a futura capital do país estaria no Planalto Central estabeleceu-se a disputa entre goianos e mineiros para sediá-la. Uns e outros entendiam que o "Planalto Central" estaria em seu território. A disputa perdurou até a escolha definitiva do sítio onde se situaria a nova Capital.

${ }^{43}$ Juscelino Kubitschek, Por que construí Brasília, p. 8. 


\section{MONTEIRO LOBATO, O ARAUTO DA PROFECIA}

O criador dos personagens Jeca-tatu, Narizinho, Pedrinho, Emília, Visconde de Sabugosa, tia Nastácia e Dona Benta do Sítio do Picapau Amarelo, o escritor Monteiro Lobato, foi fundamental para o resgate do sonho de Dom Bosco e, por conseqüência, acabou indiretamente contribuindo para a construção de Brasília no Planalto Central.

Foi Lobato quem primeiro, no Brasil, teria mencionado o sonho. Engajado na campanha de petróleo nacional, ele escreveu, em 1935, um artigo no jornal Diário de S.Paulo sob o título "Até os santos afirmam que há petróleo no Brasil", após encontrar em "amarelecida página de velha publicação salesiana, já extinta", a referência ao sonho de Dom Bosco. ${ }^{44}$

Anos mais tarde, o artigo foi resgatado pelas autoridades goianas que defendiam a mudança da capital para o interior do estado. O sonho-visão era o argumento final de que precisavam. A profecia do santo, que previra o surgimento da Terra Prometida entre os paralelos $15^{\circ}$ e $20^{\circ}$, exatamente onde seria construída Brasília, confirmaria a predestinação da nova capital.

A citação a petróleo na profecia, até então quase ignorada, ganhou eco na voz do escritor/empresário, que defendia ardorosamente a existência do ouro negro no pantanal matogrossense. ${ }^{45}$

Não deixa de ser curioso que a primeira afirmação de grandes lençóis de petróleo na América do Sul, especificamente os que se locam entre os graus 15 e 20, faixa que apanha Mato Grosso, não venha de nenhum geólogo, ou explorador de sertões, ou economista imaginativo. E sim venha de Dom Bosco, um piedoso sacerdote que por mérito de suas virtudes a Igreja Católica santificou. E isso ocorreu em 1883, numa época em que

\footnotetext{
${ }^{44}$ L. Fernando Tamanini, Brasília - Memória da Construção, p. 113.

${ }^{45}$ Monteiro Lobato, Na Antevéspera, p. 291.
} 
o petróleo estava longe de ter a importância econômica de hoje, servindo apenas, sob forma de querosene, para fins de iluminação.

(Lobato, 1959, pág. 291)

"Quem estuda o mapa na zona descrita - observou Lobato - percebe claramente que ele (Dom Bosco) só poderia estar se referindo ao grande Pantanal matogrossense".

No dia em que se desvendarem as minas ocultas nas entranhas daqueles montes, diz ele (Dom Bosco) surgirá ali a Terra da Promissão, "fluente de leite e de mel" - e será uma riqueza inconcebível.

(Lobato, 1959, pág. 292)

Para Lobato, o leite e mel de que falava Dom Bosco era o petróleo, "pois é o petróleo a grande riqueza natural que flue". Além do que, a profecia referia-se claramente, em um trecho anterior, à descoberta de "reservas de petróleo como jamais foram achadas em outros lugares".

A autenticidade do sonho foi verificada por Lobato, que constatou sua veracidade nas Memórias Biográficas de Dom Bosco, publicadas na Itália. E tratou, ele próprio de conferir legitimidade ao profeta ao conferir sua profecia sobre a Patagônia.

Os homens de espírito religioso o colocam (Dom Bosco) na classe dos seres sobrenaturais, emissários, intérpretes, da divinidade. Mas em nenhum dos grupos haverá negadores do valor da sua visualização profética, já em boa parte realizada. $O$ que Dom Bosco anteviu na Patagônia, que naquele tempo não passava dum deserto esquecido, está hoje em intensa marcha de realização. Commodoro Rivadavia é uma cidade moderníssima, a regirar em torno de quase 2.000 poços de petróleo abertos na zona. Já chegou ao estágio há 53 anos previsto por Dom Bosco, 
quando ninguém no mundo sonhava com petróleo na América do Sul e muito menos naquele terrível deserto.

Lobato conclui que, assim como aconteceu com a Patagônia, a profecia se cumpriria em relação ao Brasil, sugerindo que nessa data Dom Bosco fosse proclamado padroeiro do petróleo no Brasil.

Os fatos hão de demonstrar que, como o viu Dom Bosco, existem realmente lá "depositi di petrolio cosi abbondanti quali mai finora si trovarano in altri luoghi". E nesse dia Dom Bosco será proclamado o padroeiro do petróleo no Brasil, já que foi o primeiro homem no mundo a vê-lo e a indicar-lhe a magnitude.

Por ironia do destino, o resgate da profecia de Dom Bosco acabou servindo não aos anseios e ideais de seu descobridor, Monteiro Lobato, mas ajudou a concretizar o sonho de construção da capital do país no Planalto Central. 


\section{O MÍSTICO JK. ...E CUMPRE-SE A PROFECIA}

O fundador de Brasília, o presidente Juscelino Kubitschek, era ele próprio um místico. São várias as referências a esse aspecto de sua personalidade, relatadas nos livros de memória que escreveu sobre a construção da nova capital. O presidente do Brasil era o primeiro a acreditar que Brasília constituía-se de fato na Terra Prometida de que falava o santo na sua profecia. "No plano místico, fezse ouvir, como uma advertência profética, o tão citado sonho de São João Bosco", revela no livro de memórias Por que construí Brasília. ${ }^{46}$

Quando li essas palavras nas suas Memórias Biográficas, não deixei de me emocionar. Meditei sobre a Grande Civilização que iria surgir entre os paralelos $15^{\circ}$ e $20^{\circ}$ - justamente a área em que estava construindo, naquele momento, Brasília. O lago, da visão do santo, já figurava no Plano-Piloto do urbanista Lúcio Costa. E a Terra Prometida, anunciada repetidamente, pela misteriosa voz, ainda não existia de fato, mas já se configurava através de um anseio coletivo, que passara a constituir uma aspiração nacional. Ali, "correria leite e mel".

Nas palavras do próprio JK, "a visão de Dom Bosco fora, de fato, uma antecipação, uma advertência profética sobre o que iria ocorrer no Planalto Central a partir de 1956". ${ }^{47}$

Juscelino estava certo de que o sonha havia se tornado realidade. "Existia uma curiosa coincidência de local e de datas", constatava. Ele relembra em suas memórias que, em certa ocasião, estava no Palácio das Laranjeiras, no Rio, às duas horas da manhã, em silêncio, a recordar "palavra por palavra" o que lera no volume XVI das Memórias Biográficas de Dom Bosco. "Era a famosa profecia sobre a Grande Civilização que iria surgir entre os paralelos $15^{\circ}$ e $20^{\circ}$. ${ }^{48}$

\footnotetext{
${ }^{46}$ Juscelino Kubitschek, Por que construí Brasília, p. 19.

47 Id, Ibid., p. 19.

${ }^{48}$ Id. Cinquenta Anos em Cinco, p. 171.
} 
E veio-me à mente, outra vez, a frase profética do santo de Becchi: "E essas coisas acontecerão na terceira geração". Dom Bosco falecera em 1888. Computando-se o período de vinte anos para cada geração, era óbvio que a década dos 50 seria a da "terceira geração". As forças misteriosas que regem o mundo haviam agido no sentido de que as circunstâncias se articulassem e criassem a "oportunidade" para que o velho sonho se convertesse em realidade. Justamente na década dos 50 a idéia havia chegado à maturação, requerendo execução.

É de se destacar que a referência a "uma grande civilização" ou mesmo "civilização" não aparece em qualquer parte do sonho de Dom Bosco, conforme suas Memórias Biográficas, atenta o historiador Tamanini. Mas a expressão teria passado a fazer parte da "versão oficial" do sonho, e a ela "passariam a se reportar expressamente, com pequenas variações, todos quanto ao sonho já se referiram, ligando-o à construção de Brasília". 49

Ao realizar-se a Primeira Missa na nova capital, no dia 3 de maio de 1957, o presidente Juscelino fez o seu primeiro discurso, onde situava a dimensão mística de Brasília - "Com a Primeira Missa planta-se em Brasília uma semente espiritual. Que a cidade cresça sob o signo da esperança, da justiça e da fé", afirmou. ${ }^{50}$

A mística de Brasília, "contagiando o país inteiro, realizou o milagre da construção de uma metrópole revolucionária, em três anos e 10 meses", acreditava Juscelino. "Pobres de todas as latitudes" chegavam "em busca da Terra da Promissão". "Ali estava a Canaã, longamente sonhada”. ${ }^{51}$

Outro fato curioso que chamou a atenção de JK se deu quando o astronauta russo Yuri Gagarin, ao visitar Brasília pela primeira vez, disse-lhe: "a idéia que

\footnotetext{
${ }^{49}$ L. Fernando Tamanini, Brasília - Memória da Construção, p. 115.

50 Juscelino Kubitschek, Cinqüenta Anos em Cinco, p. 146.

${ }^{51}$ Id, Por que construí Brasília, págs. 54 e 82.
} 
tenho, presidente, é a de que estou desembarcando num planeta diferente, que não a Terra". 52

Destaque-se ainda, a defesa "surpreendente", por escrito, que o urbanista Lúcio Costa fez do seu projeto vencedor para a nova capital e que impressionou o presidente. "Nasceu do gesto primário de quem assinala um lugar ou dele toma posse; dois eixos cruzando-se em ângulo reto, ou seja, o próprio Sinal da Cruz" ${ }^{53}$ De acordo com o urbanista a proposta apresentada "surgiu" "já pronta", contribuindo para dar cores místicas ao seu projeto.

Não pretendia competir e, na verdade, não concorro apenas me desvencilho de uma solução possível, que não foi procurada, mas surgiu, por assim dizer, já pronta.

(Costa, 1957, pág. 38)

O misticismo de Juscelino em relação a Brasília não se restringia apenas à profecia de Dom Bosco. As semelhanças com a cidade do antigo Egito construída pelo faraó Aknaton o intrigavam. ${ }^{54}$

Apesar da minha formação religiosa, não escapei ao fascínio daquela estranha personalidade, misto de sonho e audácia, cuja obra de reformador constituiu, durante algum tempo, uma das preocupações do meu espírito.

Hoje, tanto tempo decorrido, pergunto-me, às vezes, se essa admiração por Akhenaton, surgida na mocidade, não constituiu a chama, distante e de certo modo romântica, que acendeu e alimentou meu ideal, realizado na maturidade, de construir, no Planalto Central, Brasília - a nova Capital do Brasil.

Apesar das coincidências e semelhanças, inclusive físicas, com Aknaton, 0 próprio Juscelino tratou de marcar as diferenças entre o presidente e o faraó. Ele

52 Juscelino Kubitschek, Por que construí Brasília, p. 11.

${ }^{5}$ Id. Ibid. p. 61.

54 Id. Meu Caminho para Brasília, p. 110. 
mesmo conta em suas memórias que a princesa Marina da Grécia, duquesa de Kent, em 1958, em visita a Brasília, ainda um gigantesco canteiro de obras teria comentado, extasiada: "O senhor constrói, Presidente, como os faraós do Antigo Egito o faziam". JK sorriu, mas corrigiu: "os faraós contruíam para os mortos, e eu construo para as gerações do futuro“. 55

Em um de seus livros sobre a construção de Brasília, o jornalista Adirson Vasconcelos confirma de forma definitiva a crença do presidente JK em relação à predestinação de Brasília, ao relatar um diálogo acontecido, no Rio de Janeiro, cerca de dois meses antes de sua morte.

- Adirson, Brasília será a Capital do Terceiro Milênio. Viva e verá. ${ }^{56}$ 


\section{ISRAEL PINHEIRO, O DEVOTO HOMENAGEIA O SANTO}

Antes de ser Prefeito de Brasília, cidade que ajudou a construir como engenheiro de confiança de JK, o mineiro Israel Pinheiro era acima de tudo um devoto de Dom Bosco. E também um místico. Israel era um estudioso da quiromancia e acreditava em previsões. Era amigo de longa data do médium Chico Xavier, que Ihe enviava com freqüência mensagens psicografadas. ${ }^{57}$

O sentimento de gratidão aos salesianos que estenderam a mão à família em momento difícil da vida e propuseram bancar sua educação, quando perdera o pai, ainda criança, estaria sempre vivo em Israel.

Foi graças à providencial ajuda de um livrinho com a profecia traduzida de Dom Bosco, espertamente produzido pelos goianos, que o mineiro Israel Pinheiro rendeu-se à idéia de construir a nova capital no planalto de Goiás e não no Triângulo mineiro. Afinal, estava lá escrito que o Santo, do qual era devoto, teria profetizado, quase um século antes, a construção de Brasília, no interior do Brasil, à altura do paralelo $15^{\circ} .^{58}$

A partir daí, Israel trataria de consolidar a ligação do santo italiano com a cidade, a qual tinha a tarefa de construir. A primeira obra que ergueu, antes de qualquer outra, foi a Ermida Dom Bosco, em homenagem ao Santo fundador da Congregação Salesiana. Um gesto de agradecimento àqueles que haviam the ajudado no passado.

Após pedir a Niemeyer o projeto da Ermida, Israel tratou do assunto com JK, que aceitou plenamente a idéia, afirmando: - Ele bem merece. Durante a conversa, ocorrida no local onde seria construído o Palácio da Alvorada, Israel propõe que a capelinha de Dom Bosco seja erguida no morro, do outro lado do Lago, de forma que o Santo ficasse de frente para a cidade que seria construída.

\footnotetext{
${ }^{57}$ Alisson Mascarenhas Vaz, Israel, uma vida para a história, p. 25.

${ }^{58}$ L. Fernando Tamanini, Brasília - Memória da Construção, p. 110.
} 
E assim foi feito. ${ }^{59}$ Anos mais tarde, a ermida foi reproduzida, em escala menor, na residência oficial de Prefeito de Brasília, a Granja do Ipê.

A Ermida ficou pronta em 31 de dezembro de 1956; contudo, somente em 24 de março de 1957 ali se celebrou a primeira missa. Com o tempo, a imagem feita de gesso e ofertada pelo Ateneu Salesiano de Goiânia foi se deteriorando e os salesianos a substituíram por outra. Em agosto daquele ano (1957) no dia 22, o Pe. Renato Ziggiotti, 5 . Sucessor de D. Bosco na Reitoria Maior da Congregação, visitando o Brasil, também celebrou a santa missa na Ermida, prometendo, na ocasião, mandar da Itália uma imagem em mármore de Carrara para substituir a de gesso, promessa que cumpriu.

Israel Pinheiro convidou os salesianos para cuidar da abertura do primeiro Colégio em Brasília, destinado aos filhos dos operários envolvidos na construção da capital. Em 30 de agosto de 1960, data do $77^{\circ}$ aniversário do Sonho-Visão de Dom Bosco, foi inaugurado, solenemente, o edifício do Colégio Dom Bosco.

${ }^{59}$ Adirson Vasconcelos, A Epopéia da Construção de Brasília, p. 75. 


\section{DOM BOSCO, PADROEIRO - A CIDADE SE CURVA AO PROFETA}

Dom Bosco está para Brasília, como Santa Genoveva está para Paris e São Sebastião para o Rio de Janeiro, "une o sobrenatural à realidade", definiu o historiador Osvaldo Orico. "Seu nome e sua obra estão associados ao destino de Brasília", vaticinou um ano após a inauguração da capital. ${ }^{60}$

Para o historiador Ernesto Silva, "Brasília não foi somente o ideal de centenas de brasileiros patriotas e capazes nem somente a esperança de milhares de patrícios abandonados do interior: um Santo também a sonhou, um Santo também a concebeu". ${ }^{61}$

Tudo caminhava para que Dom Bosco fosse o padroeiro de Brasília. A profecia já estava bastante difundida e a presença pioneira dos salesianos nos primórdios da nova capital estavam a indicar que esse seria o caminho natural. Israel Pinheiro era o principal defensor da idéia.

Porém, os bispos do Brasil, reunidos na Terceira Conferência Nacional que acontecia em São Paulo, em novembro de 1956, aprovaram por unanimidade a indicação de Nossa Senhora Aparecida para ser a padroeira da nova capital. A sugestão fora levada a Juscelino por Dom Helder Câmara, que concordou. ${ }^{62}$

No dia 5 de janeiro de 1957, os jornais divulgaram a notícia - a padroeira do Brasil seria também a padroeira de Brasília. Mas, inusitadamente, a capital ganhou o seu segundo padroeiro. De acordo com depoimento do Padre Décio Batista Teixeira, diretor geral do Instituto Israel Pinheiro, foi graças a outro devoto de Dom Bosco, o prefeito de Brasília, Paulo de Tarso, que o Santo acabou padroeiro da capital.

\footnotetext{
${ }^{60}$ Osvaldo Orico, Brasil, Capital Brasília, p. 187.

${ }^{61}$ Ernesto Silva, História de Brasília, p. 33.

${ }^{62}$ L. Fernando Tamanini, Brasília - Memórias da Construção, p. 188.
} 
No discurso de posse, Paulo de Tarso teria sugerido a indicação de Dom Bosco e o pedido foi levado ao Papa Paulo VI, em 1961, pelo Embaixador do Vaticano junto ao governo brasileiro, o Núncio Apostólico Monsenhor Lombardi. No dia 10 de junho de 1962, em ato solene, juntamente com a Virgem de Aparecida, Dom Bosco foi proclamado segundo Patrono de Brasília ou, precisamente, aequis principalis "igualmente principal". 


\section{JOÃO BOSCO - PERFIL DO PROFETA}

Para entendermos o contexto em que se deu a profecia da Terra Prometida é importante situarmos quem era Dom Bosco. Órfão de pai desde os 2 anos de idade, Giovanni Melchior Bosco, o João Bosco, nasceu em meio a uma família de humildes camponeses, em 16 de agosto de 1815, dia em que se festeja a Assunção de Maria ao céu, nos Becchi de Murialdo, pequeno pedaço do município de Castelnuovo d’Asti, na Itália.

Considerado um dos mais avançados educadores de sua época pelos seus métodos renovadores, Dom Bosco dedicou a vida à educação dos jovens meninos de rua (Ernesto Silva, p.33).

Os sonhos sempre estiveram presentes em sua vida. O primeiro aconteceu quando tinha 9 anos. Uma mensagem que influenciaria seu destino: ${ }^{63}$

"Torna-te forte, humilde e robusto. A seu tempo, tudo compreenderás. Aprende com os saltimbancos dos circos ambulantes, dá espetáculo para seus colegas, conta-lhes histórias e conquista-Ihes o coração. Leva todo mundo para a Igreja".

(Santuário Dom Bosco, 1995)

E assim o pequeno João passou a entreter os companheiros com jogos, alternados com orações e instrução religiosa. Era o início da dedicação à educação dos jovens. Aos 12 anos saiu de casa para estudar. Entrou no seminário de Chieri, foi ordenado sacerdote aos 25 anos, e logo iniciou sua obra de educador de crianças. Dedicou-se aos jovens abandonados da cidade de Turim e aos que estavam nas cadeias, encaminhando-os ao Oratório e à catequese.

\footnotetext{
${ }^{63}$ Santuário Dom Bosco, Brasília
} 
Em 1859, sob a proteção de São Francisco de Sales, fundou a Sociedade ou Congregação Salesiana, que tinha como missão educar os jovens, sobretudo os pobres e abandonados, e pregar o Evangelho nos países onde Cristo não era conhecido. Em 1872, fundou o Instituto das Filhas de Maria Auxiliadora para a educação da juventude feminina e, depois, a Associação dos Cooperados Salesianos.

Constrói, em Turim, a Basílica de Nossa Senhora Auxiliadora e funda 64 casas salesianas em seis países. Chegaram a 200 em todo o mundo, com mais de mil padres salesianos. Em 1875, envia a primeira turma de missionários à América do Sul. Foi ele quem mandou os salesianos para fundar o Colégio Santa Rosa, em Niterói, primeira casa salesiana do Brasil.

No dia 30 de agosto de 1883 Dom Bosco, aos 68 anos, teve um sonho. Um sonho que se anuncia profético e revela a Terra Prometida que surgiria entre os paralelos $15^{\circ}$ e $20^{\circ}$, região onde exatamente 76 anos, sete meses e 21 dias depois seria fundada Brasília, a capital do Brasil.

Morreu aos 72 anos de idade, em 31 de janeiro de 1888. Foi beatificado em 1929 e canonizado em 1934, pelo Papa Pio XI. No centenário da sua morte, João Paulo II proclamou-o Pai e Mestre da Juventude. São João Bosco é hoje um dos santos mais populares da Igreja e o seu dia é comemorado em 31 de janeiro, data de sua canonização. Mesmo antes mesmo de ser canonizado, era muito venerado e conhecido no Brasil como Dom Bosco.

As profecias de Dom Bosco, a maioria obtida através de sonhos, foram publicadas em 1916 na revista "Vita e Pensieri” de Milão. 


\section{O SONHO PROFÉTICO}

O "fato maravilhoso" foi contado por Dom Bosco à Assembléia Geral da Congregação Salesiana, reunida no dia 04 de setembro de 1883. Os salesianos ouviram o relato do sonho-visão que ele tivera poucos dias atrás, na noite de 29 para 30 de agosto. As descrições daquela misteriosa e extensa viagem que fizera em sonho percorrendo toda a América do Sul, de ponta a ponta, ainda estavam vivas na sua lembrança.

Parecia tudo tão real que Dom Bosco chegou a duvidar que se tratava de um sonho. O Padre Lemoyne, que registrava as memórias do Santo, transcrevia o relato, depois revisado e complementado por Dom Bosco. O sonho profético estava relacionado com as suas preocupações sobre o futuro da Congregação Salesiana e foi publicado nas páginas 385 a 394 do volume XVI das "Memorie Biografiche" de Dom Bosco, cuja primeira edição saiu em 1935.

Interessado no desenvolvimento de sua obra missionária, Dom Bosco refletia naqueles dias sobre as missões enviadas à América do Sul. Cerca de oito anos antes, em 1875, após um sonho, enviara a primeira expedição missionária à Patagônia, na Argentina meridional, e naquele ano de 1883, precisamente no dia 14 de julho, desembarcavam no Brasil os missionários que iriam fundar a primeira casa salesiana, em Niterói.

Um desses momentos de reflexão foi presenciado pelo padre Felipe Rinaldi, que viria a ser o terceiro sucessor do Santo.

Toda a preocupação de Dom Bosco estava, naqueles dias, voltada para o Brasil. Testemunha o Pe. Filipe Rinaldi, terceiro sucessor do Santo, que o surpreendera em seu quarto, contemplando enternecido um atlas que focalizava exatamente o Brasil. Suas palavras então revelaram sua esperança no futuro do 
Brasil salesiano, chegando a prever para sua obra, em nossa terra, duzentas casas! Era humanamente ridículo pensar em tão prodigioso florescimento, quando aqui se implantara apenas uma casa, que lutava com dificuldades de todo gênero.

(Santuário Dom Bosco, 1995)

No dia 30 de agosto aconteceria a festa de Santa Rosa de Lima, padroeira da América Latina, nascida em Lima, no Peru. Não por acaso, a primeira casa salesiana no Brasil seria o colégio Santa Rosa, em Niterói (RJ). Naquele dia, ao alvorecer, Dom Bosco seria acordado pelo tocar dos sinos da paróquia local. Estava despertando de um sonho profundo, que "durara a noite inteira".

No sonho, Dom Bosco guiado por um jovem "todo radiante de viva luz, mais clara que a do sol" viajou por toda a América do Sul, onde milhões de habitantes esperavam o seu auxílio, aguardam a fé. De trem, Dom Bosco percorreu florestas, montanhas, planícies, rios e ia descobrindo as riquezas dos países dessa região, que um dia seriam descobertas. Com os olhos de "uma potência visual maravilhosa", a tudo enxergava. Vislumbrou filões de metais preciosos, minas de carvão e jazidas de petróleo em grande abundância.

O principal estava por vir - a Terra Prometida estaria situada entre os graus 15 e 20 da linha do Equador. No lugar havia uma enseada bastante extensa, que partia do ponto onde se formava um lago. E uma voz repetidamente anunciou: "Quando se vierem cavar as minas escondidas em meio a estes montes, aparecerá aqui a terra prometida, que jorra leite e mel. Será uma riqueza inconcebível".

O sonho de 1883 virou profecia. Setenta e sete anos depois surgiria no Planalto Central do Brasil a cidade que os intérpretes do sonho e outros videntes consideram a capital do Terceiro Milênio. A Terra Prometida ganhou nome, a cidade um padroeiro, o profeta virou mito e a profecia realidade, perpetuada pela história oficial. 


\section{DECIFRANDO A PROFECIA}

"Quando os símbolos são interpretados espiritualmente e não concretamente, trazem a revelação". Joseph Campbell

A questão chave neste capítulo é decifrar a profecia. Tentar interpretar o sonho-visão de Dom Bosco torna-se inevitável. Teria Dom Bosco sonhado realmente com Brasília? Seria a cidade fundada por JK a Terra Prometida? Desde que essa associação foi estabelecida com a capital do país, ninguém se atreveu a contestá-la. Ao contrário, muitas teorias e interpretações surgiram para confirmála.

"Toda profecia é, de per si, obscura em seu enunciado, usando em sua expressão termos genéricos e linguagem imaginosa, figurativa", justifica o folheto que trata do sonho profético, distribuído no Santuário Dom Bosco, em Brasília, produzido pelos salesianos. Apesar disso, "é admirável notar como Dom Bosco situou nitidamente no tempo e no espaço o objetivo de sua previsão", conclui.

No sonho-visão, Dom Bosco sabe perfeitamente onde está.

"Havia, no meio daquele salão, uma mesa, sobre a qual estava enrolada uma corda. Vi que essa corda estava marcada com linhas e números, como se fosse uma fita métrica. Percebi, mais tarde, que aquele salão estava situado na América do Sul, exatamente por sobre a linha do Equador, correspondendo os números impressos na corda aos graus geográficos de latitude...".

E continua.

"Observo que então via tudo de conjunto, como que em miniatura. Depois, como direi, vi tudo em sua real grandeza e 
extensão. Foram os graus marcados na corda correspondendo exatamente aos graus geográficos de latitude, que me permitiram gravar na memória os sucessivos pontos que visitei, viajando na segunda parte do sonho".

Ainda de acordo com o sonho, já no final da viagem, o guia que acompanhava Dom Bosco tira do bolso uma carta geográfica e mostra a ele a viagem que acabara de fazer, as regiões percorridas.

Desdobrou então o mapa, em que se desenhava com admirável exatidão toda a América do Sul. Ademais, já estava representando tudo o que existia, que existe, e haverá de existir naquelas regiões, sem confusão de espécie algumas, pelo contrário, com tal nitidez que, de um só relance, se abrangia tudo. Compreendi tudo no instante, mas, pela multiplicidade das circunstâncias, durou pouco tal clareza, cedendo lugar à completa confusão que ora me ocupa a mente.

É fato que o sonho-visão de Dom Bosco não faz uma referência textual a Brasília. Na viagem pela América do Sul, Dom Bosco vislumbrou as Cordilheiras dos Andes, o Oceano Atlântico, Cartagena, na Colômbia, o Uruguai, a bacia do Prata, os pampas, a Patagônia, na Argentina, o Estreito de Magalhães.

Essa constatação em nada muda a interpretação daqueles que consideram Brasília a Terra Prometida. Outros elementos presentes no sonho são destacados para confirmar essa teoria. O mais forte deles é a referência à localização da Terra Prometida: entre os paralelos $15^{\circ}$ e $20^{\circ}$, ao sul do Equador, onde havia "uma enseada bastante extensa, que partia do ponto onde se formava um lago". Seria este o Lago Paranoá? 
A resposta oficial é sim, confirma a publicação Olhares sobre o Lago Paranoá, da Secretaria de Meio-Ambiente do Governo do Distrito Federal, segundo a qual

A interpretação oficial sustenta que a topografia dessa visão corresponde precisamente à do sítio de Brasília, construída entre o décimo quinto e o décimo sexto graus de latitude, e que o "lago que se formava" seria o lago artificial da cidade, o Paranoá.

(idem 2001, p.40, citando James Holston)

"Dom Bosco sonhou com a fundação de Brasília". A afirmação categórica está no site do Santuário Dom Bosco na Internet. ${ }^{64}$

Dom Bosco localizou a faixa compreendida pelos paralelos 15 a 20, entre a Cordilheira dos Andes e o Oceano Atlântico. Exatamente entre os paralelos 15 e 16 foi instalada a nova capital do Brasil.

O que viu Dom Bosco? Pergunta-se o folheto produzido pelo Santuário. E a resposta vem a seguir:

Embora o objeto de sua visão não seja exclusivamente nem mesmo explicitamente Brasília, podemos afirmar que Dom Bosco viu, em 1883, o que hoje, em parte, é realidade. Reforça a nossa convicção o teor mesmo da narração: "Quando vierem explorar as riquezas escondidas neste planalto, surgirá aqui a terra prometida, onde jorrará leite e mel. Será uma riqueza inconcebível". Ora, maior repercussão não obteve nenhuma outra descoberta, em outros pontos da referida faixa continental.

\footnotetext{
${ }^{64}$ www.santuáriodombosco.com.br
} 
Ademais que Dom Bosco tivesse associado ao Brasil o presente sonho, está fora de dúvida. Compreendemo-lo melhor, se recordarmos que, em 14 de julho de 1883, alguns dias antes do sonho profético, desembarcavam no Brasil os primeiros Salesianos, para dar início à primeira fundação neste país. Toda a preocupação de Dom Bosco estava, naqueles dias, voltada para o Brasil. Testemunha o Pe. Filipe Rinaldi, terceiro sucessor do Santo, que o surpreendera em seu quarto, contemplando enternecido um atlas que focalizava exatamente o Brasil. Suas palavras então revelaram sua esperança no futuro do Brasil salesiano, chegando a prever para sua obra, em nossa terra, duzentas casas! Era humanamente ridículo pensar em tão prodigioso florescimento, quando aqui se implantara apenas uma casa, que lutava com dificuldades de todo gênero.

No maravilhoso sonho que viemos examinando, Dom Bosco abraçou, na extensão que the permitiu a visão profética, o desenvolvimento de sua obra, juntamente com o progresso material da Terra. Para este, já sorri, com a inauguração da nova capital a aurora de radiante progresso, enquanto o fabuloso desenvolvimento da obra salesiana no Brasil é uma consoladora realidade.

(Brasília, Santuário D. Bosco, novembro 1995)

Observa-se que entre os graus 15 e 20, na América do Sul, há pequenos trechos de terra do Peru e do Chile, algo da Bolívia e grande extensão de terra brasileira, onde se encontra Brasília.

Transposto o grau 15, e em marcha para o grau 20, via desdobrarem-se, com clareza, imensas planuras, e montes pouco elevados, em cujas montanhas se encontravam prodigiosas riquezas minerais, inexauríveis jazidas de carvão de pedra, e 
reservas de petróleo como jamais foram achadas em outros lugares. O seio da terra, ou elevação suave, era bastante largo e longo, e emergia de um lago.

Dom Bosco relata então "as selvas amazônicas com as suas florestas intermináveis e os seus rios intrincados e enormes". Vai às malocas dos índios e, aterrorizado, diz que assiste ao sacrifício de dois missionários salesianos, abatidos a tacape pelos índios (fato que posteriormente se deu na Amazônia, em 1934, quando morreram, vítimas dos Xavantes, os padres Pedro Sacillotti e João Fuchs), confirma o historiador Ernesto Silva. ${ }^{65}$

Sem dúvida, o sonho referia-se ao futuro missionário da Congregação na América do Sul, afirma o folheto produzido pelos Salesianos e pelo Instituto Israel Pinheiro. Mas na viagem, Dom Bosco pôde contemplar também outras coisas como rios caudalosos e florestas imensas, minas de ouro, de pedras preciosas, depósitos de petróleo etc. E, claro, a Terra Prometida entre os paralelos $15^{\circ}$ e $20^{\circ}$.

Afinal, Dom Bosco sonhou Brasília? A publicação dos Salesianos é taxativa.

"Na linguagem simbólica utilizada pela voz (guia), podemos perceber uma alusão clara ao fantástico surgimento da nova capital, pois, exatamente no período e no espaço delimitados pelo sonho, o surgimento de Brasília é, sem dúvida, o acontecimento que obteve a maior repercussão sobre o progresso e 0 desenvolvimento de todo o país".

O Padre Renato Gighiotti, Superior-Geral Salesiano, ao desembarcar no Aeroporto do Galeão no Rio de Janeiro, em junho de 1957, afirmou à imprensa que Dom Bosco previu, em sonho, a localização da nova capital do Brasil no Planalto Central. ${ }^{66}$

\footnotetext{
${ }^{65}$ Ernesto Silva, História de Brasília, p. 33.

${ }^{66}$ Francisco de Assis Barbosa, Diário de Brasília, p. 91.
} 
Dom Bosco sonhou com o aparecimento de uma nova terra da promissão, situada entre os paralelos 15 e 20 no Brasil. Esta posição nos paralelos equivale a dizer que Brasília é já terra abençoada e que os planos dos engenheiros dirigidos pelo exdeputado Israel Pinheiro têm real inspiração divina.

"Brasília está para sempre ligada a Dom Bosco através daquele misterioso sonho, no qual, à distância de 75 anos, ele parece ter entrevisto o nascimento da cidade, em meio ao cerrado escaldante, sobre o planalto até então deserto". As palavras são do Papa João Paulo II, no dia 30 de junho de 1980, quando em visita a Brasília, abençoou a estátua de São João Bosco.

\section{0 anos do sonho - Quando se realizará a profecia?}

Diz o jovem:

- Isto acontecerá antes que passe a segunda geração.

Pergunta Dom Bosco:

- Qual será a segunda geração?

O jovem fala:

- A presente não conta. Será uma outra, depois outra.

E Dom Bosco, querendo ainda mais clareza:

- Quantos anos compreende cada geração?

Ele responde-Ihe:

- Sessenta anos.

\section{Primeira interpretação}

A primeira geração da Congregação dos Salesianos teve início em 1859. Segundo a determinação do jovem guia, esta geração não deve ser contada. Ao "excluí-la" a próxima teve início 60 anos depois, em 1919 estendendo-se até 1979. A partir daí, no período de 1979 a 2039 é que seria a efetiva segunda 
geração. Atribuindo-se a 2039 a data final para a realização das palavras proféticas do jovem: "Isso acontecerá antes que passe a segunda geração".

\section{Segunda interpretação}

Como escreve um dos pioneiros de Brasília e historiador local: "Para confirmar mais uma vez que São João Bosco estava se referindo à nossa capital, a Grande Civilização que ora surge no Planalto Central do Brasil, o santo afirmou que aqueles sonhos descritos seriam vividos na terceira geração" (Silva 1971:35). Em Brasília, considera-se que esse prognóstico indica um período de 75 anos, o que estabelece o final dos anos 50 como a data em que a profecia se cumpriria: exatamente o momento em que Brasília foi construída (Olhares sobre o Lago Paranoá). 


\section{SALESIANOS NO BRASIL - A FORÇA DA CONGREGAÇÃO}

A presença dos salesianos no Brasil teve início em 1883, através da Inspetoria Salesiana, com a fundação da casa salesiana de Niterói, e, em 1885, com a fundação do Liceu Coração de Jesus, em São Paulo. Desde então, as comunidades se multiplicaram e diversos grupos tornaram-se novas Inspetorias. No momento são seis, com as respectivas sedes em: Belo Horizonte (MG), Campo Grande (MS), Manaus (AM), Porto Alegre (RS), Recife (PE) e São Paulo $(\mathrm{SP})$.

Os Salesianos são uma comunidade de cristãos, fundada em 1859, pelo padre italiano Giovanni Bosco (Dom Bosco), em Turim (Itália). O nome Salesiano vem de São Francisco de Sales, Bispo de Genebra no século XVII. Dom Bosco escolheu São Francisco como patrono da sua primeira fundação devido à sua bondade, paciência e intensa caridade pastoral, qualidades necessárias para se trabalhar com a juventude.

Dom Bosco morreu em 31 de janeiro de 1888 e foi declarado santo em 1934, como Apóstolo da Juventude. Como herança, deixou aos Salesianos o "Sistema Preventivo", um método educativo que se baseia na razão, religião e bondade.

No mundo todo, os Salesianos ocupam o terceiro lugar entre as Ordens Religiosas, depois dos Jesuítas e Franciscanos. São aproximadamente 17.556 (96 bispos, 10.060 sacerdotes, 16 diáconos, 3.218 seminaristas, 2.515 religiosos leigos) distribuídos pelos cinco continentes, presentes em 118 países. Estima-se que sejam mais de 10 milhões em todo o mundo.

Sua missão está centrada na educação integral dos jovens, concretizando-se em três missões: 
Juvenil - educação de jovens e adolescentes, sobretudo os "pobres", e dos jovens chamados para o serviço na Igreja.

Popular - educação à fé nos ambientes populares, trabalhando especialmente com a Comunicação Social.

Missionária - anúncio do Evangelho aos povos que não o conhecem e presença nas jovens igrejas.

A Rede Salesiana de Escolas tem 120 anos só de Brasil. O início foi lá atrás, em 1883, em Niterói, com o Colégio Santa Rosa. De lá para cá, a Rede cresceu. Hoje são mais de 100 instituições de ensino fundamental e médio, de norte a sul do Brasil, com aproximadamente 90 mil alunos e 4 mil educadores.

São também 10 grandes universidades e centros universitários, oferecendo mais de 100 cursos, e uma rede muito ampla de obras sociais e de formação profissional. Há também uma editora, emissoras de rádio e TV e paróquias que desenvolvem vários projetos, inclusive entre os povos indígenas. 


\section{PROCISSÃO, ROCK E ORAÇÕES - A FESTA DO PADROEIRO}

Todos os anos, no último domingo de agosto, dia mais próximo à data do sonho de Dom Bosco, os brasilienses organizam uma peregrinação à Ermida Dom Bosco para recordar a visão do padre italiano que previu o surgimento da Terra Prometida na localização onde foi construída Brasília. A festa se repete desde 1961 e já faz parte do calendário de eventos turísticos e religiosos da capital.

No dia da festa é realizada uma missa campal em homenagem a Dom Bosco, patrono da cidade. Normalmente celebrada pelo arcebispo de Brasília e 12 padres auxiliares, a missa reúne populares, autoridades, religiosos, políticos e jovens que estudam nos colégios da Congregação Salesiana em Brasília.

A imagem do Santo, que fica na primeira igreja construída em sua homenagem, a Igreja do Padre Roque, no Núcleo Bandeirante, é levada em procissão de carros e motocicletas até a Ermida Dom Bosco. Lá fica exposta na tenda armada no local para a celebração da missa, onde é reverenciada pelos fiéis.

A missa termina com a chegada do cortejo náutico, que conduz outra imagem de Dom Bosco. A imagem do Santo sai do Santuário Dom Bosco em carreata até o Clube Cota Mil, às margens do Lago Paranoá e de lá segue de barco até a Ermida, em um trajeto de $1 \mathrm{~h} 45$.

A procissão náutica, realizada há 14 anos, já é uma tradição da cidade. A procissão é festiva e acompanhada por barcos e lanchas decoradas que ao final recebem uma premiação, de acordo com os temas apresentados, normalmente relacionadas à ecologia e preservação do lago.

Com o passar do tempo, foram ocorrendo alterações na festa do padroeiro e diversas atividades de lazer foram incluídas, como shows noturnos com bandas musicais de rock, sem nenhum caráter religioso. 
Em 2003, foram comemorados os 120 anos do sonho-visão de Dom Bosco. Cerca de 50 barcos enfeitaram o Lago Paranoá repetindo a tradição. A festa que já chegou a reunir 13 mil pessoas na Ermida Dom Bosco, contou com um público estimado em cinco mil pessoas durante todo o dia, conforme programação oficial a seguir.

\section{Anos do Sonho - Visão de Dom Bosco}

Programação

Data: 31 de Agosto de 2003

Local: Parque Ecológico da Ermida Dom Bosco

8h Largada da Volta Ciclística de Brasília

9h Feira de Saúde

9h Abertura da Exposição da CAESB

9h30 Chegada da procissão de motociclistas do Núcleo Bandeirante, com a imagem de Dom Bosco

9h30 Chegada do cortejo de carros antigos

$10 \mathrm{~h} 15 \quad$ Missa Campal celebrada pelos Salesianos

12h Chegada do Fogo Simbólico da Pátria

12h Apresentação da Banda Salesiana

12h30 Chegada da procissão náutica

12h30 Sobrevôo de ultraleves

13h30 Apresentação dos pára-quedistas

14h Apresentação do Bumba-meu-Boi do Mestre Teodoro

14h30 Roda de capoeira

15h Apresentação de patinadores Radicais

16h Apresentações musicais (Homem de Pedra, Blues Band)

17h Concerto ao Pôr-do-sol com a Banda do Comando Militar do Planalto

17h30 Apresentações musicais (Syang, Ligação Direta e Friends)

20h30 Show pirotécnico 


\section{CONCLUSÃO}

Segundo dados da Embratur, o turismo religioso é um nicho que movimenta, no mínimo, R\$ 6 bilhões por ano. Estudo realizado pelo Instituto de Pesquisas da Universidade de São Paulo aponta o enorme potencial desse segmento ainda pouco explorado se considerarmos a vastidão territorial do Brasil e as suas inúmeras manifestações religiosas, que misturadas à arte e cultura popular, transformam-se em verdadeiros espetáculos de devoção. São festas, novenas, procissões terrestres e fluviais, encenações teatrais, missas, cerimônias e romarias espalhadas pelas cinco regiões do país.

As perspectivas são bastante favoráveis para o turismo religioso, que beneficia a população brasileira com a geração de empregos e o aporte de recursos para as capitais e cidades do interior. De acordo com a Embratur, ${ }^{67}$ a realização de eventos dessa natureza favorece a melhor distribuição de renda e incentiva o desenvolvimento imobiliário e hoteleiro. Benefícios que se traduzem em qualidade de vida para a população local.

Em Brasília, particularmente, a Festa do Aniversário do Sonho-Visão de Dom Bosco pode tornar-se um evento de grande atração turística, especialmente se for trabalhado em parceria com a Rede Salesiana de Escolas no Brasil, com 90 mil alunos e 4 mil educadores só no ensino médio e fundamental. $E$, ainda, 10 grandes universidades e centros universitários. Um universo potencial a ser atingido e que somado a outros segmentos místicos e religiosos com certeza dará dimensão nacional e internacional ao evento.

Afinal, é fato que Brasília tornou-se um centro de referência da fé, a capital ecumênica que reúne seguidores de religiões e crenças as mais diversas e abriga o maior número de templos religiosos por $\mathrm{m}^{2}$ do país. Some-se a essa pluralidade religiosa uma característica mística ímpar. Conforme aqui mencionado, o

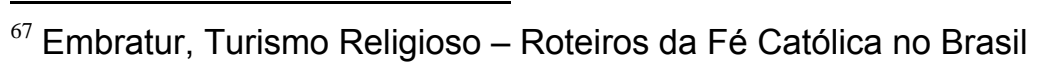


misticismo está presente na história da cidade, no seu desenho, na sua arquitetura, na sua essência. E sobre essas raízes místicas destaca--se a profecia de Dom Bosco, que permeia todas as outras crenças, da capital do terceiro milênio, da nova civilização, da Terra Prometida, de onde jorrará leite e mel.

Todas essas características, que fazem de Brasília uma cidade vocacionada para o desenvolvimento do turismo religioso, místico e espiritual, podem ser potencializadas e direcionadas para a festa que comemora o sonho-visão de Dom Bosco, transformando-a efetivamente em um evento turístico e fortalecendo a crença de que a cidade é predestinada.

A interpretação oficial confirma que a topografia da região sonhada por Dom Bosco corresponde precisamente à de Brasília, construída entre o $15^{\circ}$ e o $16^{\circ}$ de latitude e que o "lago que se formava" seria o lago artificial da cidade, o Paranoá.

O próprio Juscelino Kubitschek acreditava na visão de Dom Bosco como uma "advertência profética" e que o sonho havia se tornado realidade. Nas palavras do ex-presidente, a mística de Brasília contagiou o país inteiro e as pessoas se deslocavam para a nova capital "em busca da Terra da Promissão", a "Canaã, longamente sonhada".

Até o Papa João Paulo II ratificou a ligação espiritual de Brasília com Dom Bosco, durante benção à imagem do Santo, quando aqui esteve em 1980. "Brasília está para sempre ligada a Dom Bosco através daquele misterioso sonho", vaticinou. "Meus votos e minhas preces são para que Brasília traduza cada vez mais na realidade o sonho de um grande santo, padroeiro celeste desta Capital", completou.

As palavras do Papa reforçam a interpretação que os salesianos dão ao sonho. "Podemos afirmar que Dom Bosco viu, em 1883, o que hoje, em parte, é realidade", afirma o site do Santuário Dom Bosco. "Podemos perceber uma alusão clara ao fantástico surgimento da nova capital", acreditam. 
A força da fé salesiana pode e deve ser catalisada para o evento que comemora o aniversário do sonho-visão de Dom Bosco. Os Salesianos ocupam hoje o terceiro lugar entre as Ordens Religiosas, depois dos Jesuítas e Franciscanos, reunindo um contingente de mais de 90 mil alunos na Rede Salesiana de Escolas só aqui no Brasil.

O aniversário dos 120 anos do sonho-visão de Dom Bosco completados em 2003 e a campanha da Conferência Nacional dos Bispos do Brasil para 2005, cujo tema é o Ecumenismo, conferem oportunidade especial para investimento na festa do padroeiro da cidade, a fim de torná-la atraente do ponto de vista turístico.

As evidências reunidas neste trabalho confirmam a teoria de que, acreditese ou não, a profecia do Santo foi se materializando, o mito virou realidade e ligou Brasília para sempre a Dom Bosco e à profecia da Terra Prometida.

A festa de aniversário do sonho-visão de Dom Bosco, que é uma tradição da cidade e se realiza há 43 anos, já entrou para o calendário de eventos turísticos e religiosos da capital e pode vir a ser o maior evento místico-religioso a ser realizado em Brasília, sem igual em todo o país. 


\section{BIBLIOGRAFIA}

ADETUR - Agência de Desenvolvimento do Turismo do Distrito Federal. Brasília - Portal da Terra Prometida. Brasília: ADETUR, 2001.

BENI, Mário Carlos. Análise Estrutural do Turismo. São Paulo: Editora Senac, 1997.

BARBOSA, Francisco de Assis. Diário de Brasília. Rio de Janeiro: Presidência da República, Serviço de Documentação, 1969.

CALDAS, Lívia Dutra. Brasília Mística e Religiosa: uma visão eclética do turismo (Monografia). Brasília: Edição da Faculdade UPIS, 2001.

CAMPBELL, Joseph. O poder do mito. São Paulo: Editora Palas Athena, 1998.

CODEPLAN. Guia de informações sócio-econômicas, turísticas e culturais do Distrito Federal. Brasília: CODEPLAN, 1999.

COELHO, Margarida Haten P.. A Ermida Dom Bosco (Monografia). Brasília: Edição da Universidade de Brasília, 2004.

DIAS, Reinaldo; SILVEIRA, Emerson J.S.; GERMIANI, Haudrey; GAZONI, Jefferson L.; e GIOVANNINI, Oswaldo. Turismo Religioso: Ensaios e Reflexões. São Paulo: Editora Alínea, 2003.

EMBRATUR. Turismo Religioso, Roteiros da Fé Católica no Brasil. Brasília: Embratur, 2000.

FILHO, Abel Ambrósio da Silva. Cadernos de Turismo - Estudo comparado de edições em Brasília, Rio de Janeiro e São Paulo (Monografia). Brasília: Edição da Universidade de Brasília, 2000. 
FONSECA, Fernando Oliveira (org.). Olhares sobre o Lago Paranoá. Brasília: Secretaria de Meio Ambiente e Recursos Hídricos, 2001.

HELLERN, Victor; NOTAKER, Henry; e GAARDER, Jostein. O Livro das Religiões. São Paulo: Companhia das Letras, 2000.

HOLSTON, James. A Cidade Modernista - uma crítica de Brasília e sua utopia. São Paulo: Cia das Letras, 1993.

KERN, lara. De Aknaton a JK, das Pirâmides a Brasília. Brasília: Coronário Editora, 1995.

KUBITSCHEK, Juscelino. Porque Construí Brasília. Brasília: Senado Federal, 2000.

KUBITSCHEK, Juscelino. Meu Caminho para Brasília, vol. 2. Rio de Janeiro: Bloch Editores, 1976.

KUBITSCHEK, Juscelino. Cinqüenta Anos em Cinco. Rio de Janeiro: Bloch Editores, 1978.

LOBATO, Monteiro. Na Antevéspera. São Paulo: Editora Brasiliense, 1959.

LASSANCE, Adalberto; LOPES, Cleusa Neves da Silva; FARIAS, Darcy Dornelas; SILVA, Denise Coelho; PEREIRA, Manoel Martins. Brasília, Capital do Brasil Educação e Cultura pelo Turismo. Brasília: Pórfiro Editora/Instituto Histórico e Geográfico do Distrito Federal, 2003.

ORICO, Osvaldo. Brasil, Capital Brasília. Brasília - Rio de Janeiro: Record Editora, 1961.

SILVA, Ernesto. História de Brasília. Brasília: Editora Coordenada, 1971. 
SIQUEIRA, Deis. As novas religiosidades no Ocidente: Brasília, cidade mística. Brasília: Editora Universidade de Brasílial, 2003.

SIQUEIRA, Deis. Práticas místicas e esotéricas na capital do Brasil. VIII Jornadas sobre Alternativas Religiosas na América Latina. São Paulo, 1998.

TAMANINI, L. Fernando. Brasília, Memória da Construção, vols. 1 e 2. Brasília: Ed. Livraria Suspensa, 2003.

TAMANINI, L. Fernando. A surpreendente história do Lago Sul e outras histórias exemplares. Brasília: Editora Royal Court, 1997.

VARNHAGEN, Francisco Adolfo. A questão da capital: marítima ou interior. Brasília: Thesaurus, 1978.

VASCONCELOS, Adirson. A Epopéia da Construção de Brasília. Brasília: Gráfica do Senado, 1989.

VASCONCELOS, Adirson. A Mudança da Capital. Brasília: Edição da Gráfica e Editora Independência LTDA, 1978.

VASCONCELOS, Adirson. Memorial Brasília. Brasília: União Editora, 1995.

VAZ, Alisson Mascarenhas. Israel, uma Vida para a História. Rio de Janeiro: Companhia Vale do Rio Doce, 1996. 


\section{ANEXOS}

\section{O SONHO-VISÃO DA TERRA PROMETIDA}

"Na noite que precedia a festa de Santa Rosa de Lima, 30 de agosto, tive um sonho. Percebi que estava dormindo e parecia-me, ao mesmo tempo, correr a toda velocidade, a ponto de me sentir cansado de correr, de falar, de escrever e de esforçarme no desempenho das ocupações costumeiras.

Enquanto hesitava se se tratava de sonho ou de realidade, pareceu-me entrar em um salão, onde se achavam muitas pessoas, falando de assuntos vários".

O Santo relata então o assunto da conversa e, mais adiante, prossegue.

“...Nesse interim, aproximou-se de mim um jovem de seus 16 anos, amável e de beleza sobre-humana, todo radiante de viva luz, mais clara que a do sol...".

Dom Bosco, então descreve o seu guia nessa viagem misteriosa, que se apresenta como amigo seu e dos Salesianos: vem em nome de Deus, dar-lhe um pouco de trabalho.

“- Vejamos de que se trata. Que trabalho é esse?

- Sente-se a esta mesa e puxe esta corda.

Havia, no meio daquele salão, uma mesa, sobre a qual estava enrolada uma corda. Vi que essa corda estava marcada com linhas e números, como se fosse uma fita métrica. Percebi, mais tarde, que aquele salão estava situado na América do Sul, exatamente por sobre a linha do Equador, correspondendo os números impressos na corda aos graus geográficos de latitude...".

Dom Bosco segue, então, a descrever a vista de conjunto da América do Sul:

"Observo que então via tudo de conjunto, como que em miniatura. Depois, como direi, vi tudo em sua real grandeza e extensão. Foram os graus marcados na corda correspondendo exatamente aos graus geográficos de latitude, que me permitiram gravar na memória os sucessivos pontos que visitei, viajando na segunda parte do sonho.

Meu jovem amigo continuava: - Pois bem, estas montanhas são como balisas: são um limite. Entre elas e o mar está a messe oferecida aos Salesianos. São milhares, são 
milhões de habitantes que esperam o seu auxílio: aguardam a fé. Aquelas montanhas eram as Cordilheiras da América do Sul e aquele mar o Oceano Atlântico...".

A visão prossegue mostrando a Dom Bosco como conseguiria guiar tantos povos ao rebanho de Cristo.

"Eu ia pensando: Mas para se conseguir isto, vai ser preciso muito tempo. Enfim, exclamei em voz alta: Não sei mais o que responder.

Mas o moço, lendo meus pensamentos, ajuntou:

- Isto acontecerá antes que passe a segunda geração. - E qual será a segunda geração? - A presente não se conta. Será uma outra, depois outra. - E quantos anos compreende cada geração dessas? - Sessenta anos. - E depois? - Quer ver o que sucederá depois? Venha cá. E sem saber como, encontrei-me numa estação de estrada de ferro. Havia muita gente. Embarcamos.

Perguntei onde estávamos. Respondeu o moço:

-Note bem! Observe! Viajaremos ao longo da cordilheira. O senhor tem estrada franqueada também para leste, até o mar. É outro dom do Senhor".

Assim dizendo, tirou do bolso um mapa, que mostrava assinalada a diocese de Cartagena (Colômbia). Era o ponto de partida.

"Enquanto olhava o mapa, a máquina apitou e o trem se pôs em movimento. Viajando, meu amigo falava muito, mas nem tudo eu podia entender, por causa do barulho do comboio. Aprendi, no entanto, coisas belíssimas e inteiramente novas sobre astronomia, náutica, meteorologia, sobre a fauna, a flora e a topografia daqueles lugares, que ele me explicava com maravilhosa precisão...

la olhando através das janelas do vagão e descortinava variadas e estupendas regiões. Bosques, montanhas, planícies, rios tão grandes e majestosos que não era capaz de os acreditar assim tão caudalosos, longe que estavam da foz. Por mais de mil milhas, costeamos uma floresta virgem, inexplorada ainda hoje. Meus olhos tinham uma potência visual maravilhosa, não encontrando obstáculos que os detivessem de estenderse por aquelas regiões. 
Enxergava nas vísceras das montanhas e no subsolo das planícies. Tinha debaixo dos olhos as riquezas incomparáveis daqueles países, riquezas que um dia serão descobertas. Via numerosos filões de metais preciosos, minas inexauríveis de carvão, depósitos de petróleo tão abundantes como nunca se encontraram até então em outros lugares.

Mas não era tudo. Entre o grau 15 e o 20, havia uma enseada bastante extensa, que partia do ponto onde se formava um lago. Disse então uma voz repetidamente: Quando se vierem cavar as minas escondidas em meio a estes montes, aparecerá aqui a terra prometida, que jorrará leite e mel. Será uma riqueza inconcebível".

Continua a viagem, ao longo da cordilheira, rumo ao sul.

"De novo pôs-se o trem em movimento, indo sempre para a frente. Como na primeira parte da viagem, atravessamos florestas, passávamos por túneis e viadutos gigantescos, internávamos por entre gargantas, costeávamos lagos e pantanais, transpúnhamos caudalosos rios, percorríamos, enfim, pradarias e planícies. Passamos, assim, às margens do Uruguai".

Dom Bosco continua a descrever as regiões fronteiriças, através da bacia do Prata, dos Pampas e da Patagônia, até o Estreito de Magalhães. Começa a viagem de volta. Na Patagônia, Dom Bosco se entretém com os seus salesianos (de gerações futuras). Atravessa a Argentina, penetra em uma floresta muito espêssa, enorme, onde presencia o massacre de um estrangeiro, entregue à sanha de ferozes canibais.

Prossegue às margens de caudaloso rio, atravessando, afinal, uma região infestada de animais ferozes e de répteis repelentes. Estão chegando ao fim da viagem:

“O trem se aproxima do lugar da partida e já estávamos a pouca distância. O jovem guia tirou do bolso uma carta geográfica de incrível beleza e me disse:

- Quer ver a viagem que o senhor fez? As regiões percorridas?

- Com muito gosto. 
Desdobrou então o mapa, em que se desenhava com admirável exatidão toda a América do Sul. Ademais, já estava representando tudo o que existia, que existe, e haverá de existir naquelas regiões, sem confusão de espécie algumas, pelo contrário, com tal nitidez que, de um só relance, se abrangia tudo. Compreendi tudo no instante, mas, pela multiplicidade das circunstâncias, durou pouco tal clareza, cedendo lugar à completa confusão que ora me ocupa a mente.

Enquanto observava aquele mapa, esperando que o rapazinho acrescentasse ainda alguma explicação, agitado que estava pela surpresa de tudo quanto vira, pareceume que soassem as Ave-Marias, ao alvorecer. Despertando, percebi que eram os sinos da paróquia de São Benigno.

O sonho durara a noite inteira". 


\section{DISCORSO DI GIOVANNI PAOLO II PER LA BENEDIZIONE DEL MONUMENTO A SAN GIOVANNI BOSCO}

Brasilia, 30 giugno 1980

Sto per compiere ora un gesto di estrema semplicità, ma anche di profondo significato: la benedizione di questa statua di San Giovanni Bosco, Don Bosco, come lo chiamano affettuosamente, anche molti anni dopo la sua canonizzazione.

Brasilia è legata per sempre a Don Bosco attraverso quel misterioso sogno, nel quale, a distanza di 75 anni, pare che abbia intravisto la nascita della città, in mezzo allo sterpaio cocente, sull'altipiano fino allora deserto.

$\mathrm{Nel}$ benedire questa immagine, rendo un sentito omaggio di venerazione al caro santo dei giovani, padre di intrepidi e infaticabili missionari del vicino Mato Grosso e di Goiás, eletto patrono celeste di questa capitale. Lo faccio come se lo facessi nella sua graziosa e solitaria cappelletta, che segnò gli inizi di Brasilia, dove sarà portata e dove sarà venerata questa immagine, o nel suo magnifico santuario nella città.

Auguro e prego perché Brasilia traduca sempre meglio nella realtà il sogno di un grande santo. I giovani, prediletti di Don Bosco, qui crescano con la possibilità di conoscere e vivere il Vangelo. Le famiglie realizzino l'ideale della Sacra Famiglia di Nazaret. Brasilia sia sempre una città per persone umane: accogliente, fraterna, serena. Fioriscano qui belle comunità cristiane. Sorgano, in queste famiglie e in queste comunità, belle e promettenti vocazioni sacerdotali e religiose.

Con questi sentimenti e auguri, benedico di tutto cuore questa immagine. 
ORAÇÃO DE DOM BOSCO

Ó Pai, pela vossa misericórdia, São João Bosco anunciou as insondáveis riquezas de Cristo.

Concedei-nos, por sua intercessão, crescer no vosso conhecimento e viver na vossa presença segundo o Evangelho, frutificando em boas obras.

Por Nosso Senhor Jesus Cristo, vosso filho, na unidade do Espírito Santo. Amém. 